University of Nebraska - Lincoln

DigitalCommons@University of Nebraska - Lincoln

2008

Design of a naturalized flow regime-an example from the Lower

Missouri River, USA

Robert B. Jacobson

U.S. Geological Survey-CERC, rjacobson@usgs.gov

David L. Galat

U.S. Geological Survey - University of Missouri, galatd@missouri.edu

Follow this and additional works at: https://digitalcommons.unl.edu/usgsstaffpub

Jacobson, Robert B. and Galat, David L., "Design of a naturalized flow regime-an example from the Lower Missouri River, USA" (2008). USGS Staff -- Published Research. 597.

https://digitalcommons.unl.edu/usgsstaffpub/597

This Article is brought to you for free and open access by the US Geological Survey at DigitalCommons@University of Nebraska - Lincoln. It has been accepted for inclusion in USGS Staff -- Published Research by an authorized administrator of DigitalCommons@University of Nebraska - Lincoln. 


\title{
Design of a naturalized flow regime-an example from the Lower Missouri River, USA ${ }^{\dagger}$
}

\author{
Robert B. Jacobson ${ }^{1 *}$ and David L. Galat ${ }^{2}$ \\ ${ }^{1}$ U.S. Geological Survey-CERC, Columbia, Missouri, USA \\ ${ }^{2}$ U.S. Geological Survey - University of Missouri, Cooperative Research Unit, Columbia, Missouri, USA
}

\begin{abstract}
A group of river managers, stakeholders, and scientists met during summer 2005 to design a more naturalized flow regime for the Lower Missouri River (LMOR). The objective was to comply with requirements under the U.S. Endangered Species Act to support reproduction and survival of threatened and endangered species, with emphasis on the endangered pallid sturgeon (Scaphirhynchus albus), while minimizing negative effects to existing social and economic benefits of prevailing river management. Specific hydrograph requirements for pallid sturgeon reproduction are unknown, hence much of the design process was based on features of the natural flow regime. Environmental flow components (EFCs) extracted from the reference natural flow regime were used to design and assess performance of alternative flow regimes.

The design process incorporated a primary stage in which conceptual hydrographs were developed and assessed for their general ecological and social-economic performance. The second stage accounted for hydroclimatic variation by coding the conceptual hydrographs into reservoir release rules, adding constraints for downstream flooding and low-storage precludes, and running the rules through 100 years of hydroclimatic simulation. The output flow regimes were then evaluated for presumed ecological benefits based on how closely they resembled EFCs in the reference natural flow regime. Flow regimes also were assessed for social-economic cost indicators, including days of flooding of low-lying agricultural land, days over flood stage, and storage levels in system reservoirs.

Our experience with flow-regime design on the LMOR underscored the lack of confidence the stakeholders place in the value of the natural flow regime as a measure of ecosystem benefit in the absence of fundamental scientific documentation. Stakeholders desired proof of ecological benefits commensurate with the certainty of economic losses. We also gained insight into the processes of integrating science into a collaborative management exercise. Although the 2005 collaborative effort failed to reach a consensus among stakeholders on a naturalized flow regime, the process was successful in pilot-testing a design approach; it helped focus scienctific efforts on key knowledge gaps; and it demonstrated the potential for collaborations among scientists, stakeholders, and managers in river management decision making. Copyright (c) 2008 John Wiley \& Sons, Ltd.
\end{abstract}

KEY WORDS flow regime; hydrology; Missouri River; pallid sturgeon

Received 3 October 2007; Accepted 21 February 2008

\section{INTRODUCTION}

Naturalization of the flow regime has become a paradigm in river restoration and management (Poff et al., 1997; Richter et al., 1997; Tharme, 2003; Arthington et al., 2006). In intensively engineered, multipurpose rivers like the Missouri (Figure 1), society expects that benefits of restoration will be balanced with social and economic river values, including hydropower, water supply, navigation, recreation, and flood control (Gore and Shields, 1995). The process of designing ecologically beneficial, naturalized flow regimes on multipurpose rivers is encumbered by a disparity of information among competing management objectives. Typically, social and economic values of water are well quantified, whereas ecological values are not (Bunn and Arthington, 2002).

\footnotetext{
* Correspondence to: Robert B. Jacobson, USGS-CERC, Columbia, Missouri, USA. E-mail: rjacobson@usgs.gov

$\dagger$ This article is a U.S Government work and is in the public domain in
} the U.S.A.
Increasingly, decision-making strategies strive to incorporate a wide range of stakeholders' views in river management and restoration (Ostdahl et al., 2001; Zockler et al., 2001; Buijse et al., 2002; Robinson and Whitton, 2004; Rogers, 2006).

The objective of this article is to relate the experience of designing a naturalized flow regime on the Lower Missouri River (LMOR, Figure 1) to theories and practice of ecological flow management. Stakeholders, scientists, and managers met during the summer of 2005 under the auspices of the Missouri River Plenary Group (Plenary Group) to attempt to design biologically effective spring flow pulses on the LMOR. This effort was stipulated in a Biological Opinion (U.S. Fish and Wildlife Service, $2000,2003)$ as a reasonable and prudent measure to remove the endangered pallid sturgeon (Scaphirhynchus albus) from jeopardy under the U.S. Endangered Species Act. This same Biological Opinion also stipulated measures to support two listed birds that nest and rear their young on exposed sandbars along the Missouri River: the threatened piping plover (Charadrius melodus), and the 


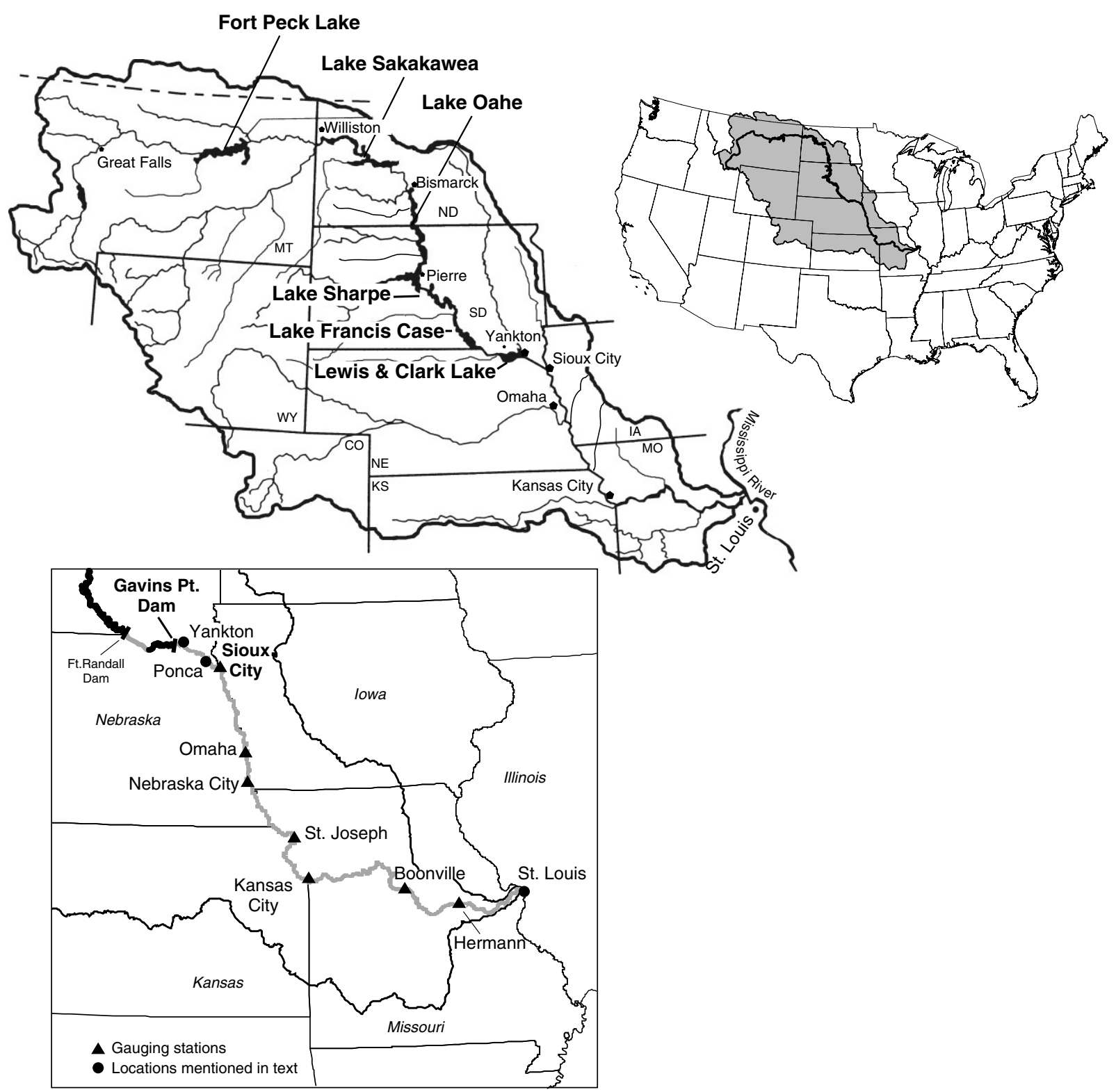

Figure 1. Missouri River Basin, Lower Missouri River (LMOR), and locations discussed in the text. The LMOR is defined as the river downstream of Gavins Point Dam, near Yankton, South Dakota and upstream of the confluence with the Mississippi River in St Louis, Missouri.

endangered interior least tern (Sternula antillarum athalassos). In contrast to a vision of holistic restoration of the Missouri River (National Research Council, 2002), this effort at flow-regime naturalization was strongly constrained by actions authorized by the Endangered Species Act, and a host of other applicable legislation and legal mandates, (Thorson, 1994; National Research Council, 2002; Lambrecht, 2005).

Although many approaches to designing flow regimes have been proposed and are in practice (Tharme, 2003), they provided only general guidance for the specific issues of the LMOR. This case study illustrates practical challenges to flow-regime design for large, multipurpose river systems and it indicates how general approaches to designing ecological flow regimes may need to evolve to accommodate management constraints and stakeholders' expectations.

\section{Flow-regime design}

Design of flow regimes to meet multiple purposes requires three fundamental types of information (Bovee et al., 1998): (1) contextual understanding of the physiography, climate, and social, economic, and historical framework of the river; (2) characterization of the time series of discharge and associated sediment, water quality, temperature, and geomorphic regimes under management alternatives, and; (3) response functions relating ecosystem and social-economic variables to flow variables. Typically, these three types of information are integrated within a decision-making framework to design and assess alternative flow regimes (Figure 2).

Contextual information is fundamental to the process because river characteristics can be strongly influenced by spatial variation in geologic controls, climatic regimes, 


\section{BASIC INFORMATION} NEEDS
SYNTHESIS AND INTEGRATION

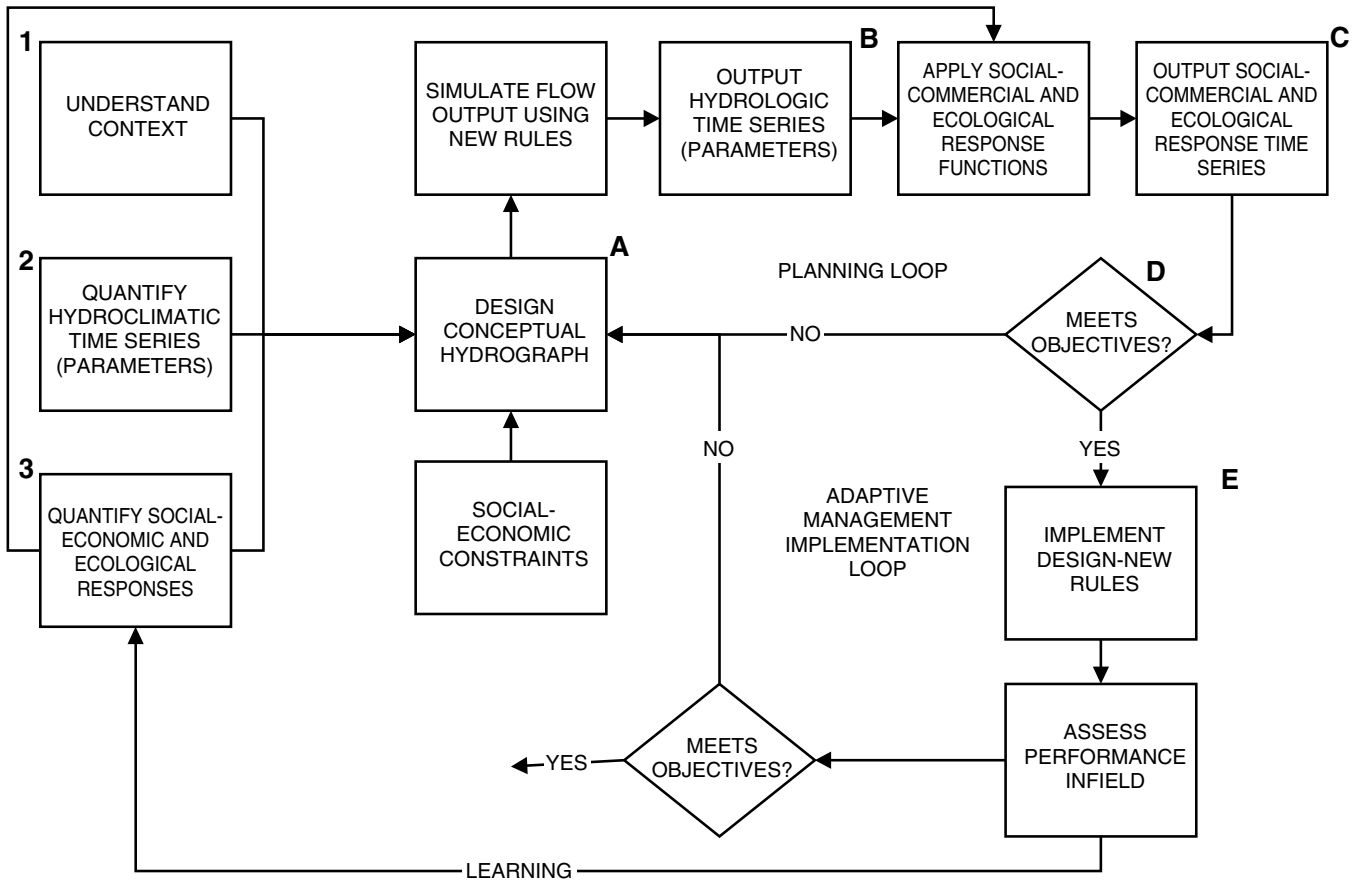

Figure 2. Schematic of typical assessment process for water allocations for ecological needs (after IFIM, Bovee et al., 1998). Diagram is described in text.

and the history of adjustments to river management (Hillman and Brierley, 2002; Grant et al., 2003; Rogers and O'Keeffe, 2003; Jacobson and Galat, 2006). Information on hydroclimatic time series addresses temporal variation of water discharge, and by extension, much of the temporal variation in related variables like sediment flux, water temperature, and water quality. In natural river systems, these related variables can be expected to co-vary to maintain ecosystem processes (Poff et al., 1997); however, in managed systems reservoir regulation can decouple the other variables from discharge, so naturalization of the flow regime may not restore other processes (Ligon et al., 1995; Schmidt and Wilcock, in press). A complete flow-regime design for ecosystem purposes would include independent assessments of controls on the other variables and how they interact with discharge (Bovee et al., 1998).

The third type of information comprises functional relations between flow-regime variables and ecosystem and social-economic responses. Typically, social and economic responses to varying flow-management designs are well-quantified, whereas ecological responses are not (Pigram, 2000; Bunn and Arthington, 2002; Sklar et al., 2005). How much ecological information is needed to inform flow-regime design depends on many factors, including the political and economic context, data availability, and the willingness of stakeholders to bear risks of uncertainty (Pahl-Wostl et al., 2007).

In the ideal design process, the three types of information are brought together to create conceptual hydrograph alternatives (Figure 2(A)). This process can be a 'topdown' or 'holistic' approach in which the natural flow regime provides a starting template that is altered to meet competing demands (Arthington, 1998a). Alternatively, a conceptual annual hydrograph can be built from the 'bottom up' by identifying ecological (and socialeconomic) functions that should be accommodated in the flow regime (King et al., 2003). In the case of large, multipurpose river systems, the capability may exist to code the conceptual models into simulation models that output hydrologic time series, which, in turn, can be used to drive models to predict time series of ecological and social-economic responses (Figure 2(B) and (C)).

In the planning loop illustrated in Figure 2, the time series of outputs of the ecological and social-economic models would be assessed for their performance in enhancing ecological functions and providing socialeconomic services (Figure 2(D)). If a model fails to meet objectives, alternative conceptual models would be formulated to be tested through the same procedure. If the predictions from the planning loop meet objectives, the concepts would be applied in the real world (Figure 2(E)) in an adaptive management implementation loop that acknowledges residual uncertainties in the planning process and explicitly accommodates learning (Walters, 1997).

Assessments of designs on large rivers are complicated by the need to accommodate multiple, often conflicting, objectives, and by the typical disparity of information content between ecological and social-economic 


\section{NATURAL DRIVERS}

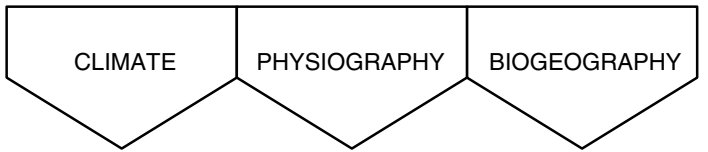

NATURAL

SYSTEM

FRAMEWORK

AND FLUXES

HUMAN-

INDUCED

CHANGE

TIER 2 EEC

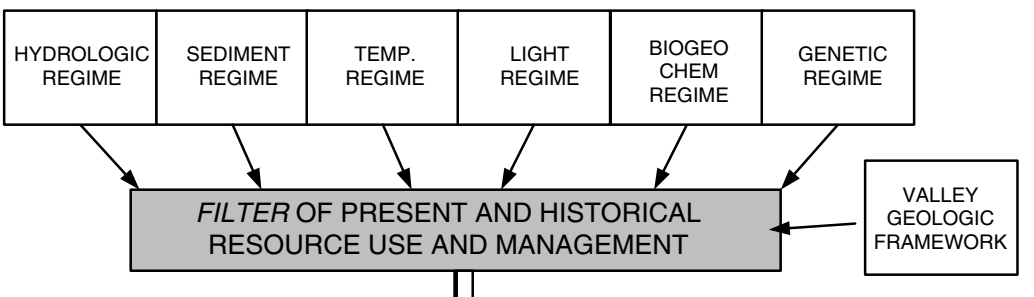

TIER 1 EEC

TIER 3 EEC

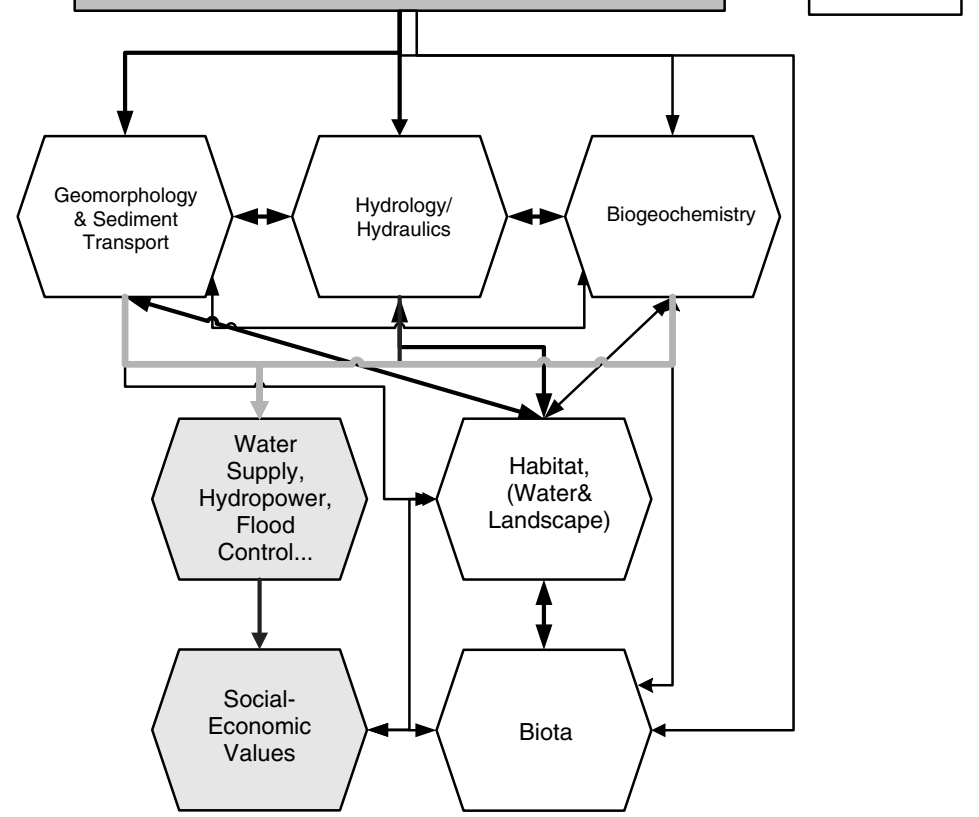

Figure 3. Conceptual diagram of elements affecting flow regime and ecological responses to management actions, based on the concept of essential ecosystem characteristics (EECs, Harwell et al., 1999). Flow regime is considered a master variable. However, in altered river systems-especially dammed river systems - flow regime can be uncoupled from sediment, nutrients, temperature, and other regimes. Effects of management are first evident in the ecosystem in Tier 1 EECs as direct effects. These effects propagate through habitat and biota EECs, typically becoming less clearly linked to management. On the basis of Lubinksi and Barko (2003).

response functions. This disparity is illustrated conceptually in Figure 3, a simple realization of a river ecosystem consisting of drivers, regimes, and essential ecosystem characteristics (EECs). EECs are defined to group a wide range of ecosystem characteristics and processes into classes that are meaningful to scientists, managers, and stakeholders (Harwell et al., 1999) and can be viewed in three tiers based on the strength of their linkages to management actions. Uncertainty in predicting river responses grows as management effects propagate through tiers of ecological structure and function of a river system. Tier 1 is composed of geomorphology, hydrology/hydraulics, and bio-geochemistry EECs that will have measurable endpoints directly linkable to the management action - for example, low pulse magnitudes, sediment concentrations, dissolved oxygen, water velocities. On the right side of the diagram, Tier 2 consists of the broadly defined habitat EEC - the integration of physical, chemical, and biotic factors that determine the space in which organisms of interest reside. The Tier 3 EECs relate specifically to biota of interest, and can be defined as population, community, or individual health metrics. Social and economic characteristics (shown in light grey on the left) are parallel to the ecological components. Interactions of social values and biota EECs indicate the trade offs that underlie many river management decisions (Figure 3).

Many (but not all) pathways identified in the conceptual model indicate propagation of management actions through Tier 1 and Tier 2 EECs before affecting biota or social values in Tier 3. Because relations among EECs are characterized by interactions, feedbacks, and uncertainties, the linkages are more direct for Tier 1 and least direct - subject to more complexity and uncertainty — for Tier 3. Information needed to assess Tier 1 EEC's linkage to management is generally less costly and more certain than that needed to assess linkage to the Tier 3 EEC.

One of the challenges to designing alternative flow regimes is determining the level of scientific information needed to inform the decision-making process: whether it is necessary to predict very accurately what the ecosystem response will be to a change in flow regime, or whether it 
is acceptable to infer the response from measurements or predictions of Tier 1 or Tier 2 EECs that are more directly linked to management. A second, related challenge is reconciling the precise information content typically available to assess social-economic responses (left side of Figure 3) with the less-precise information available to assess ecological functions (right side of Figure 3. These two challenges were central in the design process undertaken by the Missouri River Plenary Group, and they are likely generic to river-management decision processes world-wide.

\section{Lower Missouri River}

The Missouri River drains $137100 \mathrm{~km}^{2}$ of North America (Galat et al., 2005a). The drainage basin encompasses wide latitudinal and longitudinal diversity, with annual precipitation varying from less than $300 \mathrm{~mm} / \mathrm{year}$ in the western plains to more than $1000 \mathrm{~mm} /$ year at its confluence with the Mississippi River near St Louis, Missouri. Snowpack in the Rocky Mountains on the western margin of the basin can attain thicknesses of greater than $4 \mathrm{~m}$ and acts to store winter precipitation for seasonal summer releases. The central and eastern parts of the basin are susceptible to high-intensity run-off from summer convective storms. Mean annual discharge at Hermann, Missouri near the mouth is $2250 \mathrm{~m}^{3} / \mathrm{s}$. Reservoirs in the Missouri River basin provide a total of over $130 \mathrm{~km}^{3}$ of storage; $91 \mathrm{~km}^{3}$ of this storage is provided by the mainstem system of six reservoirs that impounds $53 \%$ of the drainage basin.

The mainstem reservoir system has substantially altered the flow regime (Figure 4). The six mainstem reservoirs were constructed between 1937 and 1963 and operation as system began in 1967 (U.S. Army Corps of Engineers, 2004b). The system is managed for multiple purposes including maintenance of navigation flows, flood control, hydropower, public water supply, recreation, and fish and wildlife resources. Galat and Lipkin (2000) documented substantial alteration to the annual hydrograph below the reservoirs, including reduced intraannual flow variability with generally decreased spring pulses and increased summer low flows. The intensity of hydrologic alteration diminishes somewhat downstream from the dams as tributaries enter the Missouri River. The $590 \mathrm{~km}$ downstream of the Kansas River confluence (at Kansas City, Missouri) has increased summer low flows relative to natural levels, but retains substantial intra-annual variability including spring-summer flow pulses (Figure 4).

In addition to flow-regime changes, the LMOR has been subjected to interacting changes in sediment regime and channel morphology. The sediment regime of the river also has been substantially altered as a result of reservoir operations (Blevins, 2006). Before reservoir construction annual sediment load of the Missouri River measured just above the Mississippi River confluence was $288 \mathrm{mmt}$ (Keown et al., 1986); after reservoir construction it had decreased to $68 \mathrm{mmt}$ in the 1990s (Horowitz,

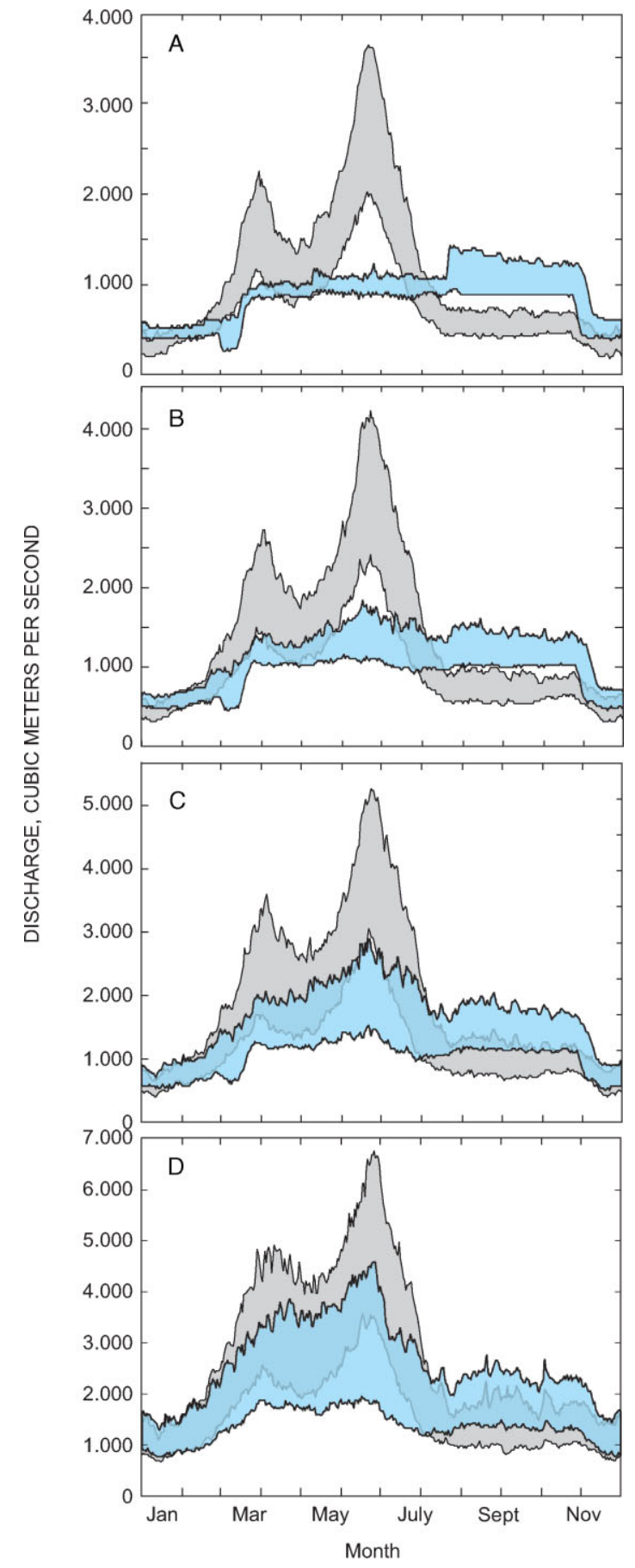

Figure 4. Duration hydrographs showing variation in $25-75 \%$ flow exceedances with downstream location on the Lower Missouri River. Grey bands are the reference (run of the river) flow regime. Blue bands are the current water control plan (2004). Data from the U.S. Army Corps of Engineers Daily Routing Model (U.S. Army Corps of Engineers, 1998). (A) Sioux City, Iowa. (B) Nebraska City, Nebraska. (C) Kansas City, Missouri. (D) Hermann, Missouri.

2003). The decrease in sediment load also has been associated with decreases in turbidity that might directly affect native fish fauna (Galat et al., 2005b).

Most of the LMOR (defined as the 1305-km section between Gavins Point Dam and the confluence with the Mississippi River, Figure 1) has been engineered for bank stabilization and navigation. Engineering of the channel of the LMOR began in the 1830s with 
clearing of large woody debris and bank stabilization to improve conditions for steamboat navigation. Most of the river's engineering structures date from 1930 to 1970 (Ferrell, 1996). Presently, wing dikes and revetments stabilize $1200 \mathrm{~km}$ of riverbanks, while narrowing and focussing flow in the thalweg to maintain a self-dredging navigation channel. These engineering structures have created a narrow, swift, and deep channel from what was historically a shallow, shifting, braided river, resulting in the loss of as much as $400 \mathrm{~km}^{2}$ of river -corridor habitats (Funk and Robinson, 1974; Hesse and Sheets, 1993; National Research Council, 2002; Galat et al., 2005a).

\section{Flow-regime design objectives}

Because the flow regime of the LMOR has been highly altered by reservoir regulation, it has been implicated as a proximal cause for decline of native species (National Research Council, 2002; U.S. Fish and Wildlife Service, 2003). Biological information to support this inference includes the general decline of native fish species, commercial fish catches (Hesse, 1987; Pflieger and Grace, 1987; Hesse et al., 1989; Hesse and Sheets, 1993; Galat et al., 2005a) and sandbar-nesting birds (U.S. Fish and Wildlife Service, 2000) in the LMOR since regulation and channelization. There is also some statistical evidence relating greater catch-per-unit-effort of native cyprinid and catostomid species to increased rising spring discharges (Hay, 2006). The design objective for the 2005 Plenary Group meeting was therefore to restore elements of the natural variability of the flow regime to support endangered species, principally the endangered pallid sturgeon, and two sandbar-nesting birds, the least tern and piping plover (U.S. Fish and Wildlife Service, 2003).

Although other groups have articulated much broader goals for Missouri River restoration (National Research Council, 2002), the institutional and legal context of the 2005 design process limited the design objectives. The scope of flow-regime changes was determined through the formal consultation process under Section 7 of the U.S. Endangered Species Act in which the U.S. Fish and Wildlife Service issued a Biological Opinion (U.S. Fish and Wildlife Service, 2000, 2003) detailing how management of the river has affected protected species, and suggested management actions. The critical processes of the flow regime initially listed by the U.S. Fish and Wildlife Service (2003) were:

1. building sandbars in $95 \mathrm{~km}$ of the LMOR downstream from Gavins Point Dam, to support nesting of threatened and endangered bird species,

2. connecting the main channel to the floodplain seasonally, to augment nutrient and energy exchange, and to provide fish access to overbank habitats,

3. maintaining nursery habitat for larval and juvenile pallid sturgeon by achieving seasonal low flows in late summer,

4. providing an environmental spawning cue for the pallid sturgeon through some combination of discharge and discharge-related variables like temperature, turbidity, and water velocity,

5. providing spawning habitat and/or 'conditioning' of spawning habitat for pallid sturgeon by flushing fine sediment from coarse substrate.

The scope of objectives for flow-regime design was subsequently narrowed by U.S. Army Corps of Engineers (2003b) (hereafter Corps) arguments that building sandbars, reconnecting the floodplain, and providing lowwater nursery habitat were unrealistic under current operating constraints. Discharges needed to transport sand, scour encroaching vegetation, or connect the floodplain would conflict with flood-control benefits (U.S. Army Corps of Engineers, 2003a). Moreover, channel incision, channelization, and levees have limited the area of floodplain that would be inundated by managed flood pulses (U.S. Army Corps of Engineers, 2003a, 2004a; Jacobson and Galat, 2006).

Similarly, low summer flows to support larval and juvenile nursery habitat for pallid sturgeon would conflict directly with navigation on the LMOR (U.S. Army Corps of Engineers, 2003b) and habitat gains would not be large because of historical channelization (U.S. Army Corps of Engineers, 2003a; Jacobson and Galat, 2006; Tracy-Smith, 2006). These arguments for limiting flowregime design objectives were generally, although not universally, acknowledged by participants in the Plenary Group process. Hence, as an initial step in adaptive management of sturgeon reproduction and survival, it was agreed that design objectives would be restricted to the role of spring-flow pulses in providing environmental spawning cues and/or changing the quality or quantity of spawning habitat for pallid sturgeon.

\section{State of biological knowledge: pallid sturgeon spawning} requirements

Design of an alternative flow regime was challenged by incomplete knowledge of the spawning requirements of the pallid sturgeon. Although there is general agreement that many large-river fishes require natural variability of the flow regime for a range of life-history activities (Junk et al., 1989; Poff et al., 1997), specific spawning requirements of pallid sturgeon are not known (Keenlyne and Jenkins, 1993; Quist et al., 2004; U.S. Fish and Wildlife Service, 2007; Wildhaber et al., 2007).

Environmental factors considered to be primary drivers of reproductive development, spawning migrations, and spawning of riverine fishes in general include photoperiod, water temperature, and river flow (De Vlaming, 1972; Welcomme, 1985; Lucas and Baras, 2001). Specifically, these three factors have been suggested as environmental cues governing reproduction of sturgeons and paddlefishes (Doroshov, 1985; Doroshov et al., 1997; Quist et al., 2004). Photoperiod is unaffected by river management, leaving temperature and river flow as potential design variables by the Plenary Group.

Some links between spawning and hydrologic variables can be inferred from indirect evidence. Spawning 
of the closely related and abundant shovelnose sturgeon (Scaphirhynchus platorynchus) is believed to occur over hard substrates (i.e. rock, rubble, or gravel) in primary tributary streams or along borders of main river channels (Keenlyne, 1997). Although actual spawning has not been observed, captures of fish in spawning condition indicates that shovelnose sturgeon spawn from 14.4 to $24^{\circ} \mathrm{C}$ beginning with initial appearance of spent females to the last observation of females with large black eggs (Helms, 1974; Christenson, 1975; Elser et al., 1977; Moos, 1978; Hurley, 1983; Keenlyne, 1997). Hatchery propagation uses $18{ }^{\circ} \mathrm{C}$ as the optimal temperature for pallid sturgeon spawning (Herb Bollig, U.S. Fish and Wildlife Service, personal communication). Pallid sturgeons, like shovelnose sturgeon, have been observed to possess mature gametes during periods coinciding with high river flows. These observations are the primary basis for associating the onset of spawning for both species with typical spring flooding in rivers (Dryer and Sandvol, 1993; Mayden and Kuhajda, 1997).

In addition, studies of Acipsenseridae provide weightof-evidence support for hypotheses that temperature and flow regime may affect migration, spawning site selection, and spawning of Scaphirhynchus sturgeon. Hydrologic spawning cues have been indentified for Gulf sturgeon (Acipenser oxrinchus de sotoi; Chapman and Carr, 1995), white sturgeon (Acipenser transmontanus, (Parsley et al., 1993; Paragamian and Kruse, 2001; Paragamian et al., 2001), shortnose sturgeon (Acipenser brevirostrum, (Buckley and Kynard, 1985)) and lake sturgeon (Acipenser fluvescens, (Noakes et al., 1999)). Importantly, spawning activity of Acipenser sturgeons can be disrupted by varying flow regimes downstream from hydroelectric dams (Noakes et al., 1999; Paragamian and Kruse, 2001), unusually high discharge (Kynard, 1997), or abrupt temperature declines (Burch and Binkowski, 2002).

Availability of suitable spawning habitat is critical to reproductive success of sturgeons and spawning site fidelity is high in some species (Bemis and Kynard, 1997). Sturgeons are litho-pelagophiles, depositing demersal (sinking) adhesive eggs that typically attach to hard substrates. Newly hatched larvae become buoyant and are dispersed by river flow. The hypothesis that spring-pulse flows would operate to clean off spawning substrate is based on similar processes that have been documented with other sturgeon species, notably the Kootenai white sturgeon. Lack of successful spawning for white sturgeon has been attributed in part to lack of hard spawning substrate that has been cleared of sand (Paragamian and Kruse, 2001; Paragamian et al., 2001) and studies have been conducted to estimate the flows needed to flush sediment from spawning beds (Barton et al., 2005; Berenbrock and Bennet, 2005).

Spring pulses may operate similarly on the LMOR to clean sturgeon spawning substrate or make it available at specific times during the year, but there are currently no scientific studies to support these conjectures. Only lately has there been a systematic attempt to identify and map the presence of gravel-cobble substrate in the river (Laustrup et al., 2007) and to identify spawning sites (Korschgen, 2007). Hence, the concept that spring pulses would serve to condition or alter availability of spawning substrate (goal 5) remains hypothetical on the LMOR. It has also been proposed that sturgeon eggs can drift with the current as much as $1 \mathrm{~km} /$ day (Paragamian et al., 2001; Coutant, 2004). If this is true for pallid and shovelnose sturgeon eggs, then sediment transport and patch structure of habitats immediately downstream of spawning sites also may be important in the immediate post-spawn period.

Whereas many studies have associated aspects of a river's flow regime with sturgeon- spawning migrations and spawning success, we are unaware of specific research that has shown a direct link between sturgeon reproductive success and a spring-flow pulse. Evidence supporting a causal relation requires demonstrating that successful spawning and hatching of larvae occur in years with a spring-flow pulse, but is absent or greatly reduced in years without a spring rise. Without this evidence, we viewed the design objectives as both goals and hypotheses to be tested through adaptive management.

\section{DESIGN APPROACH}

Given sparse understanding of the reproductive requirements of pallid sturgeon, it was not possible to guide the LMOR design process with quantitative response functions as envisioned in the diagram in Figure 2. As a practical alternative, we combined analysis of the natural flow regime and used available biological understanding and social-economic requirements as constraints. The natural flow regime provides a range of specific parameters (date of peaks, magnitude of pulses, duration of pulses, rate of rise, and rate of fall) that can be used to design alternative flow regimes (Richter et al., 1996, 1997; The Nature Conservancy, 2005). The natural flow regime can also provide a systematic basis for evaluating relative performance of alternatives whether or not they have been designed from the natural flow regime.

Design from the natural flow regime is conceptually very similar to the flow translucency approach (Gippel, 2001), in which the natural flow regime provides an understanding of the spectrum of magnitude, frequency, and timing of flow. Elements of the natural flow are then scaled down to accommodate diminished, regulated flows while maintaining flow variability. In the next section we describe how in the case of the LMOR, spring pulses were isolated and scaled downward from the median to attempt to reach a point at which both ecologic and socialeconomic interests were satisfied.

\section{Methods}

This analysis focuses on flows released at Gavins Point Dam (Figure 1). Performance assessment for ecological objectives uses the streamflow gaging station at Sioux City, Iowa, $125 \mathrm{~km}$ downstream from Gavins Point Dam. 
Five steps were used to design a naturalized flow regime: (1) modelling the reference flow regime, (2) extraction of ecologically meaningful characteristics of the flow regime, (3) comparison with temperature and photoperiod data, (4) synthesis of alternative conceptual flow scenarios, and (5) comparison of modelled outcomes.

Modelling the reference flow regime. We used the natural flow regime of LMOR as a design template and as a performance reference. Systematic statistical approaches have been defined for how to analyse flow regimes in terms of variables considered important to many ecological processes (Richter et al., 1997, 2003). Hydrologic modelling provided a mechanism to assess a long unregulated discharge record, address climatic variability, and simulate flow regimes for management alternatives.

The Corps of Engineers' Daily Routing Model (DRM) (U.S. Army Corps of Engineers, 1998) synthesizes LMOR flows based on historical data on tributary inflows, calculations of streamflow depletions due to evapotranspiration and consumptive use, and modifications of outflows according to water-control rules. The model simulates how reservoirs would be managed under a set of water-control rules, given the actual range of variability of historical inflow data. Historical inflow data are available, or have been estimated, for the period 1898-1997. The DRM uses these data and water-control rules to generate 100 years of daily flows for 14 locations on the mainstream Missouri River. The 14 locations consist of nine streamflow-gaging stations on the LMOR and five streamflow-gaging sites in interreservoir river segments.

Of particular importance in our analysis is the modelled-flow regime for the run-of-the river (ROR) scenario. The ROR scenario estimates the natural flow regime by modelling the river as if the reservoirs are constantly full and simply passing inflows through them (U.S. Army Corps of Engineers, 1998). Although this model underestimates the flow somewhat in the summer because of overestimation of evapotranspiration from the lake surfaces, it does a reasonable job of modellingknown historical flows (Figure 5), especially the spring pulses considered in this analysis.

Parsing ecological flow components. A systematic approach to analysing hydrographs for ecologically meaningful characteristics was developed by Richter et al. (1996). Their approach extracts as many as 67 hydrologic parameters from natural and altered hydrographs to evaluate type and degree of alteration (The Nature Conservancy, 2005). A subset of these parameters is called the environmental flow components (EFC) group, which extracts information about low-flow events and high-flow pulses (Figure 6(A)). The concept of EFCs is used in our analysis, although the complexity of the Missouri River hydrograph and the design task required us to write custom computer code to extract information on flow pulses.
A fundamental challenge in applying the concept of EFCs is parsing the continuous hydrograph into pieces that can be considered biologically significant pulses. In the extreme case, every event of rising, peaking, and declining discharge could be identified as a pulse, although it is unlikely that each of these would be ecologically significant. In the ideal case, ecological criteria would be available to define absolute discharge thresholds or rates of change that could be used to discriminate which pulses are significant.

Without such criteria, we used a two-step approach in which the statistical properties of the population of all possible pulses in the flow regime were subsequently used to parameterize extraction of a subset of pulses that were thought to be ecologically significant. The procedure was automated by Perl scripts (Practical Extraction and Report Language, ActiveState Corporation, Vancouver, British Columbia). The basic steps were:

1. Develop an unfiltered pulse dataset (UPD) from the ROR flow regime by identifying each rising, falling, flat, and peak component of the time series.

a. Beginnings and endings of pulses were identified as changes in slope from decreasing to increasing.

b. Peaks were identified as points or portions of the time series in which increasing discharge was followed by decreasing discharge.

c. Because hydrographs of regulated rivers are prone to plateau periods of no measurable change, a criterion was needed to assign a plateau to peaks or flats. We used 7 days as a maximum plateau to be identified as a peak.

d. Each pulse was attributed with start date, start discharge, peak date, peak discharge, end date, and end discharge.

2. Calculate simple EFCs for each of the UPD pulses (Table I).

3. Tabulate quantiles of the UPD pulses.

4. Iteratively test various quantiles for their utility as parameters for extracting subsets of pulses of the UPD, and for combining subordinate pulses into dominant pulses. This is a subjective calibration step, in which pulses are eliminated, combined, and extracted depending on the magnitude of EFCs relative to quantiles of the UPD EFCs. For example, a pulse with a rising peak magnitude less than the 10th percentile of the UPD rising peak magnitude would be eliminated from consideration if it was not part of a succeeding larger pulse, or it would be combined with the next pulse if together they exceeded the 10th percentile criterion. The criterion we used for successful calibration was how well the values delineated and extracted individual early and late spring flow pulses from the natural flow regime of the LMOR (Figure 6(B)).

5. Once calibrated from the ROR flow regime, similar parameter values were used on all alternativemanaged flow scenarios. Extraction of filtered pulses was based on: 

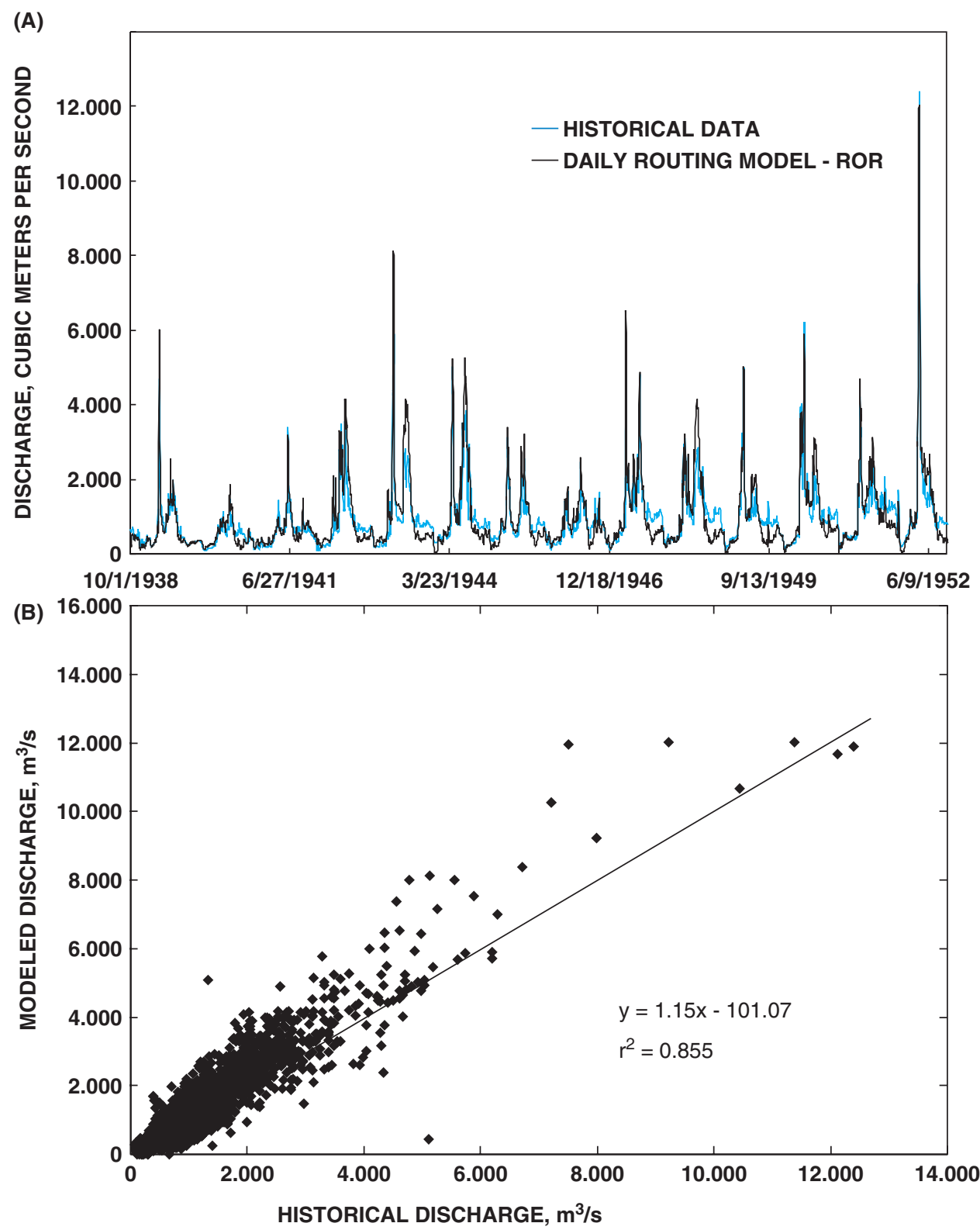

Figure 5. (A) Example of Daily Routing Model performance, measured and modelled daily discharges, Missouri River at Sioux City, Iowa. (B) Scatter plot of modelled and measured discharges, Missouri River at Sioux City, Iowa.

a. A primary criterion required candidate pulse peaks to equal or exceed the median discharge.

b. EFCs were calculated for pulses that met this first criterion, and tested against a second criterion:

- The duration must equal or exceed the median duration of the UPD.

- Either the relative rise or the relative fall must exceed the 75 th percentile of those variables from the UPD.

c. If the pulse failed to meet the second criterion, it was combined with the next pulse, and retested against the second criterion.

d. The next pulse in the time series was combined with any pulse meeting the second criterion if the relative rise to the next pulse peak was less than or equal to the 75 th percentile of relative rise in the UPD.
6. New EFCs were calculated from redefined starts, peaks, and ends of the filtered pulses, and tabulated.

7. All discharge values in the time series were then reclassified as pulses or non-pulses.

The design process on LMOR also needed to differentiate between the early and late spring pulses, because of the possibility that they had different ecological functions. The early pulse was defined as having the peak date between 1 March and 30 April. The later pulse was similarly defined as having the peak date between 1 May and 31 July. The pulses may start or end beyond these dates, but the pulses are differentiated from the record as those with peaks that occur within these date windows. EFCs for all pulses were imported into a spreadsheet programme where they were filtered into early and late 

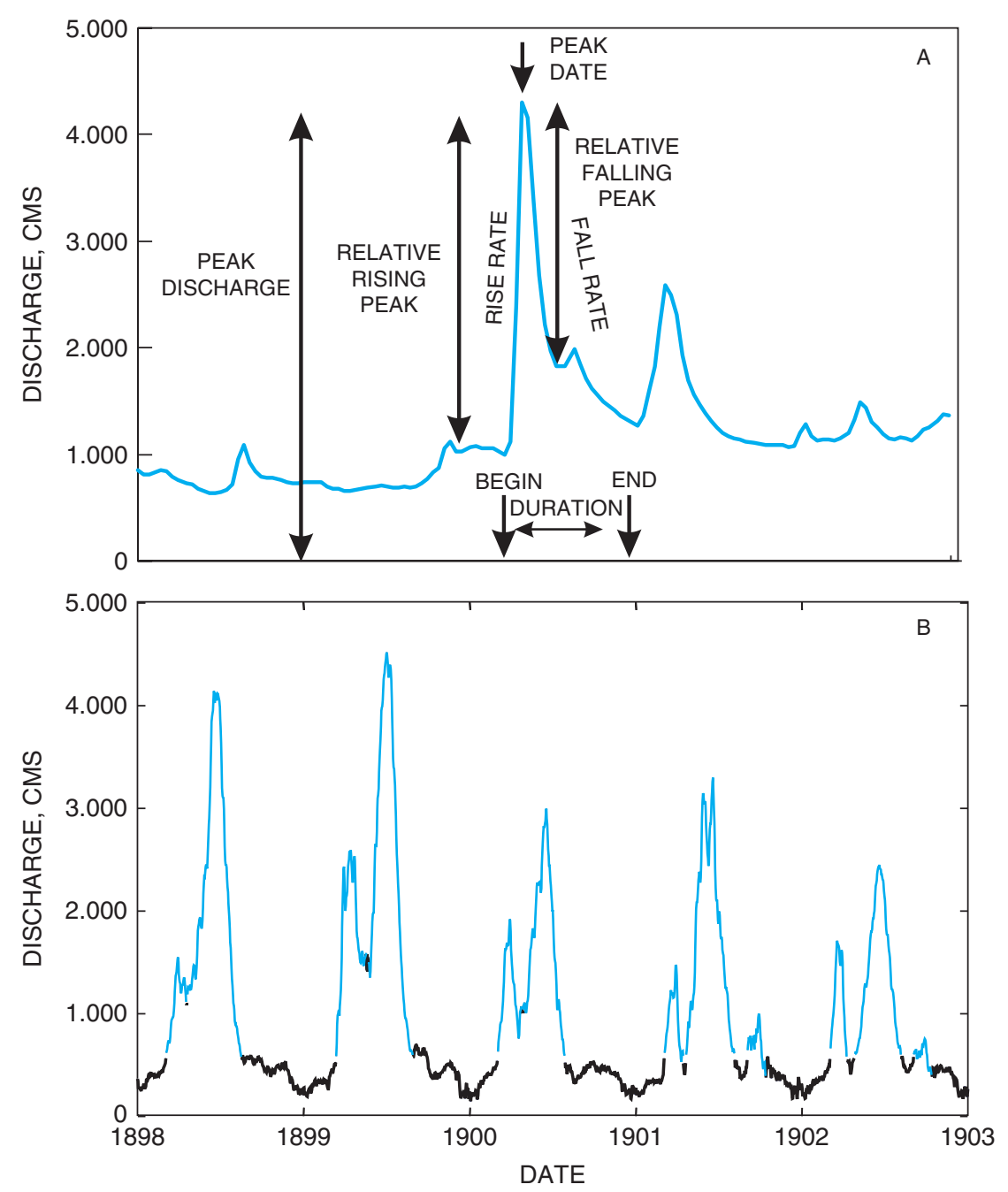

Figure 6. (A) Diagram showing the ecological flow components (EFCs) extracted from the Missouri River flow regime. (B) Portion of the reference flow regime showing parsing and separation of dominant bimodal spring pulses.

pulses based on the criteria listed, analysed statistically, and graphed.

Water temperature and photoperiod. We included photoperiod and seasonal water temperature in design because of evidence that flow pulses may need to be synchronized with these variables for successful spawning. Both were treated as independent seasonally varying variables.

Unlike many reservoir systems, water temperature on the LMOR is minimally affected by reservoir releases. Volume of Lewis and Clark Lake impounded by Gavins Point Dam is small $\left(0.61 \mathrm{~km}^{3}\right)$ and the lake is shallow (mean depth $4.9 \mathrm{~m}$; Galat et al., 2005a). Consequently, water has a short residence time (exchange rate 0.04 years) and water temperatures coming out of the power generation facility track seasonal air temperatures fairly closely. Water temperatures are substantially more equilibrated with air temperature $125 \mathrm{~km}$ downstream at Sioux City (Figure 7(A)). Short-term discharge pulses, whether from reservoir releases or local run-off events, tend to cool river water slightly, imposing shortterm variation on the seasonal trend (Figure 7(B), (C)).

Table I. Simple environmental flow components (EFCs) used in flow-regime analysis.

\begin{tabular}{lcc}
\hline $\begin{array}{l}\text { Environmental } \\
\text { flow component }\end{array}$ & Calculation & Units \\
\hline $\begin{array}{l}\text { Duration } \\
\text { Relative rising peak }\end{array}$ & (End date) $-($ Start date $)$ & Days \\
Rate of rise & (Peak discharge) $-($ Start discharge $)$ & $\mathrm{m}^{3} / \mathrm{s}$ \\
Relative falling peak & (Relative rising peak) $/(($ Peak date $)-($ End date $))$ & $\mathrm{m}^{3} / \mathrm{s} / \mathrm{d}$ \\
Rate of fall & (Peak discharge) $-($ Start discharge $)$ & $\mathrm{m}^{3} / \mathrm{s}$ \\
Relative peak & (Relative rising peak) $/(($ Peak date $)-($ End date $))$ & $\mathrm{m}^{3} / \mathrm{s} / \mathrm{d}$ \\
& Greater of relative rising peak and relative falling peak & $\mathrm{m}^{3} / \mathrm{s}$
\end{tabular}



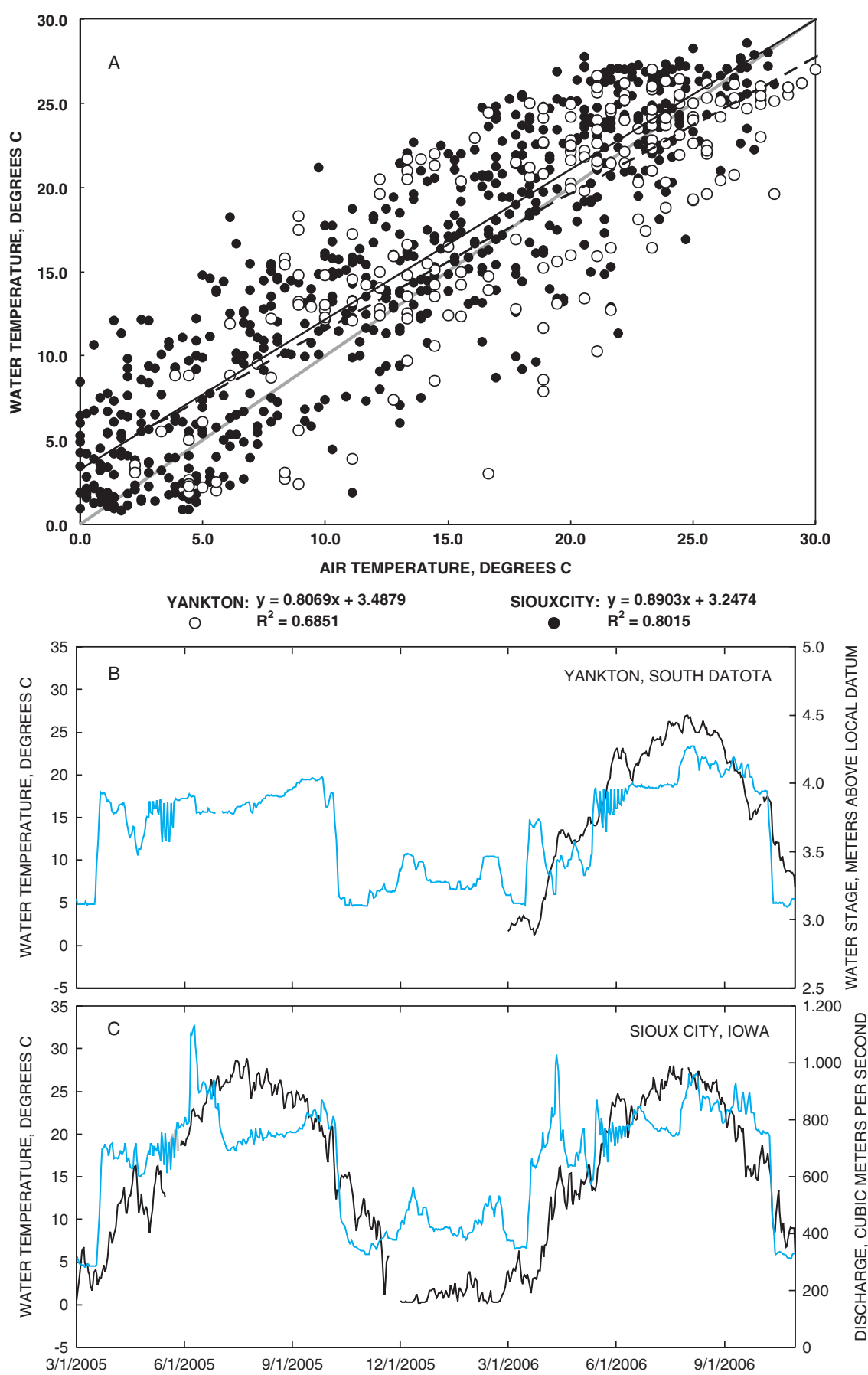

Figure 7. Relation among discharge, water temperature, and air temperature, LMOR between Gavins Point Dam and Sioux City, Iowa. Yankton, South Dakota is $9.8 \mathrm{~km}$ downstream of Gavins Point Dam and Sioux City, Iowa is $125 \mathrm{~km}$ downstream. (A) Relation between air temperature and water temperature at Yankton, South Dakota and Sioux City, Iowa. (B) Discharge and water temperature at Yankton, 2005-2006. Water temperature data were not available during 2005. (C) Discharge and water temperature at Sioux City, 2005-2006. Water temperatures dominantly track seasonal air temperatures, with minor departures due to weather events or local run-off. Water temperatures in early spring appear to be more sensitive to discharge events than water temperatures in late spring and summer.

Temperature sensitivity to flow events is most evident in the early spring. The lack of seasonal sensitivity of water temperature to flow releases allowed us to treat water temperature as an independent variable defined by long-term climatic conditions, rather than a variable that interacts strongly with discharge. Water and air temperature data at Sioux City were used to determine dates when spawning temperatures would be expected to be achieved over the long term.
Although timing of the second pulse was designed to coincide generally with seasonal warmer water temperatures and annual maximum photoperiod, more specific temperature criteria were designed to serve as the operational trigger for the release. Plenary Group scientists agreed that the start of the second rise should occur on or shortly after Missouri River water temperatures at Gavins Point Dam reached $16{ }^{\circ} \mathrm{C}$ for the second time during the season. This criterion was intended to couple initiation 


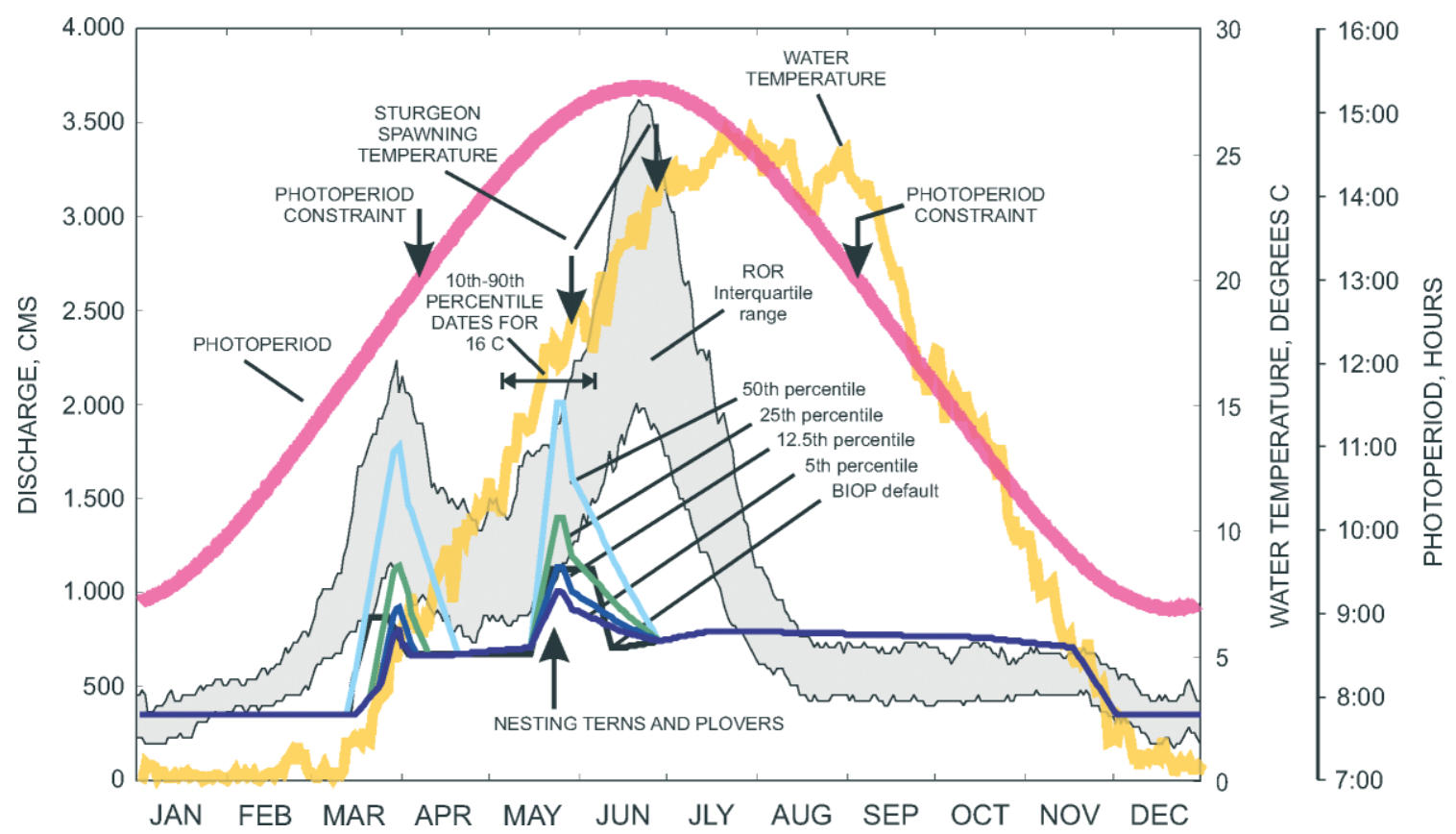

Figure 8. Conceptual spring-pulse hydrographs with magnitudes and durations based on percentiles of the run-of-the-river reference hydrograph, with late peak date altered to minimize interference with nesting shorebirds. Photoperiod, water temperatures, and daily inter-quartile range of run-of-the-river flow regime are shown for comparison.

of the flow pulse with rising water temperatures slightly below the temperature when pallid sturgeons are suspected to spawn. The 90th to 10th percentile dates when $16{ }^{\circ} \mathrm{C}$ occurred for the second time based on Missouri River water temperatures both below Gavins Point Dam and at Sioux City were 10 May to 6 June, respectively (Figure 8), defining a broad window within which the second pulse could be triggered.

Increasing photoperiod is likely to control initiation of gametogenesis in sturgeons as it does in bony fishes (Doroshov et al., 1997) and therefore was considered important in reproduction of the pallid sturgeon. Annual photoperiod at Sioux City is also shown in Figure 8. Anecdotal historical information supported a minimum photoperiod of $13 \mathrm{~h}$ for Missouri River sturgeon spawning, indicating photoperiod was less of a constraint on timing of the second pulse than temperature (Figure 8).

Management for other species. The Plenary Group design process focussed on spring pulses necessary to promote spawning of the pallid sturgeon, but any changes in flow regime had to avoid conflict with reproduction and survival with the listed interior least tern and piping plover. Although flow-regime management is not currently called on to create the sandbars on which these birds nest, flow regimes are managed to maximize sandbar emergence and minimize flooding of their nests from May-July (U.S. Fish and Wildlife Service, 2003; U.S. Army Corps of Engineers, 2004b). Historically, bare sandbars were probably maintained at higher elevations than they are today because of the higher frequency of floods capable of scouring vegetation and depositing sand at those elevations. Higher-elevation surfaces would have provided more nesting habitat at safe elevations above spring pulses. Under present-day conditions, nests are concentrated closer to the water's edge and are therefore at risk of inundation from spring-pulse flows.

Migration of nesting terns and plovers into the Gavins Point-Sioux City segment of the river occurs in midMay. Specific design guidance to protect nests was to initiate the late pulse on or before 19 May with a peak flow on or before 22 May (Figure 8; Michael Olson, U.S. Fish and Wildlife Service, personal communication). This departure from the natural timing may serve to desynchronize pulses from water temperature and photoperiod, a possibility that was acknowledged as a compromise for multi-species management (U.S. Fish and Wildlife Service, 2003). However, timing of the second pulse to minimize flooding of nests could still be accomplished within the temperature and photoperiod constraints for pallid sturgeon spawning, as currently known (Figure 8).

Synthesizing pulsed-flow regimes. Statistical parameters of pulse peak dates, peak discharges, relative rising peak discharges, durations, and rates of rise and fall (Figure 6(A), Table II) were extracted from the ROR flow regime for design guidelines and to compare performance of synthesized flow regimes. The early and late peaks were analysed separately to provide two sets of design guides.

The statistical analysis of the flow regime was provided to the Plenary Group as scientific information that could inform the design process, but the actual process was a negotiation that involved a wide range of perceptions, policy positions, and values. In the process, conceptual hydrograph designs were developed by three subgroups 


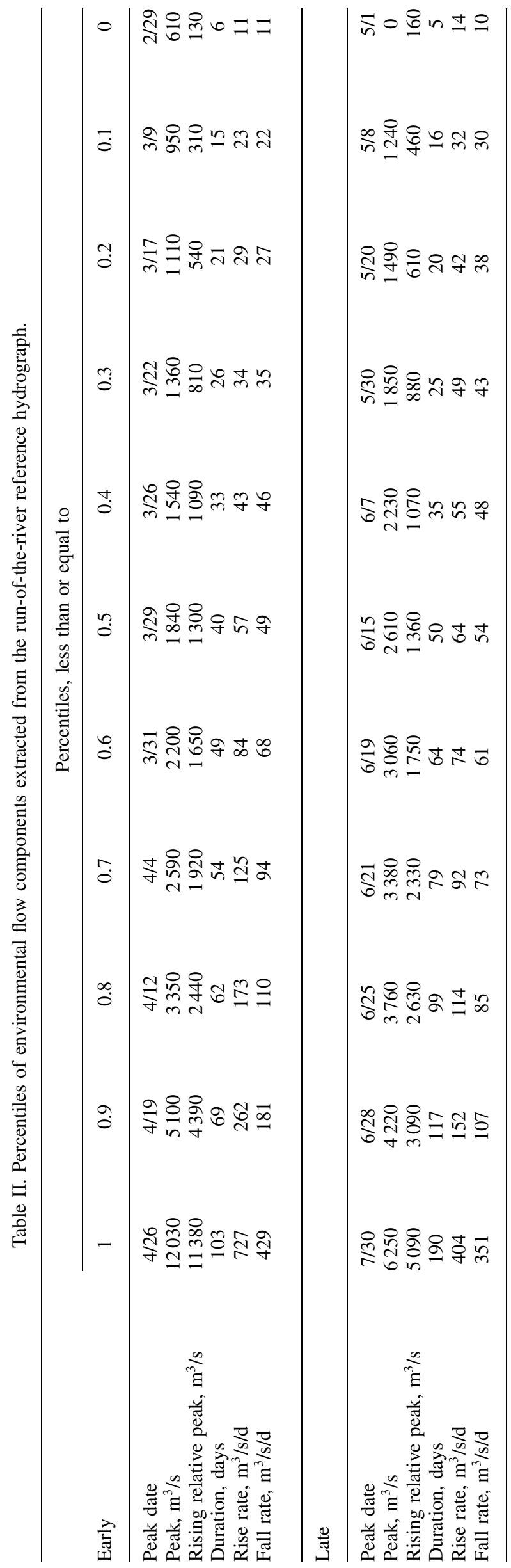

composed of managers, stakeholders, and scientists representing similar interests (pallid sturgeon, hydrology, and social-economic) with the objectives of achieving some combination of naturalized spring pulses and minimized social-economic cost. A subset of the designs developed by the Pallid Sturgeon Group used percentiles of rising relative peak and duration of pulses in the reference-flow regime to create conceptual hydrographs (Figure 8 and Reference Flow (RF) series Table III). The Hydrology Group (hydrological management unit (HMU)) series, Table III) proposed pulses that were somewhat smaller and more peaked than the RF series, and the SocialEconomic Group (socioeconomic classification (SEC)) series, Table III) proposed pulses that rose and fell very fast relative to the others to minimize water use. In all designs, the conceptual hydrographs were constructed by adding the pulse components to a default navigation hydrograph (for example, Figure 8).

For the RF series conceptual hydrographs, dates to begin pulses were calculated as peak dates minus time needed to reach the peak given median rates of rise from the ROR flow regime. The time at peak was set to 2 days because the natural hydrograph had relatively short peaks and sturgeon experts felt it was the peak itself or the rise to the peak, rather than its duration, that provided migration/spawning cues for sturgeon. A kinked fall was designed with $30 \%$ decrease over 3 days, and the remainder of the declining limb constructed to meet the design duration (Figure 8). Dates of pulse peaks in the conceptual hydrographs were not estimated from the dates in reference flow regime, but instead were set through negotiation to minimize conflict with other management purposes. The early peak date was set to coincide with increased releases at the beginning of navigation season and the second peak date was placed to minimize interference with bird nesting. The start of the navigation season, 1 April, is near the 60th percentile of the natural flow regime's early peak date ( Table II), and therefore is consistent with the natural flow regime. The latest acceptable date for a second peak to avoid conflict with shorebird nesting (22 May) is substantially earlier in the year than that of the reference flow regime, at about the 25th percentile of the natural flow-regime peak date (Figure 8). The interval 10-19 May was recommended for the start of the second peak because these days would generally coincide with water temperatures of $16^{\circ} \mathrm{C}$ and a rise starting on these dates would not jeopardize bird nesting.

The RF group used the relative rising peak (Figure 6(A)) for design and assessment, rather than the absolute peak, because most fish experts thought that the pulse's role as a spawning cue would be measured as a relative increase in discharge and associated waterquality characteristics. Absolute discharge may be more important for fish that spawn in floodplains or if eggs or larvae require habitats that would only be available during high flows (Coutant, 2004).

Conceptual hydrographs in the first stage of design (A, Figure 2), were presented to the Plenary Group 


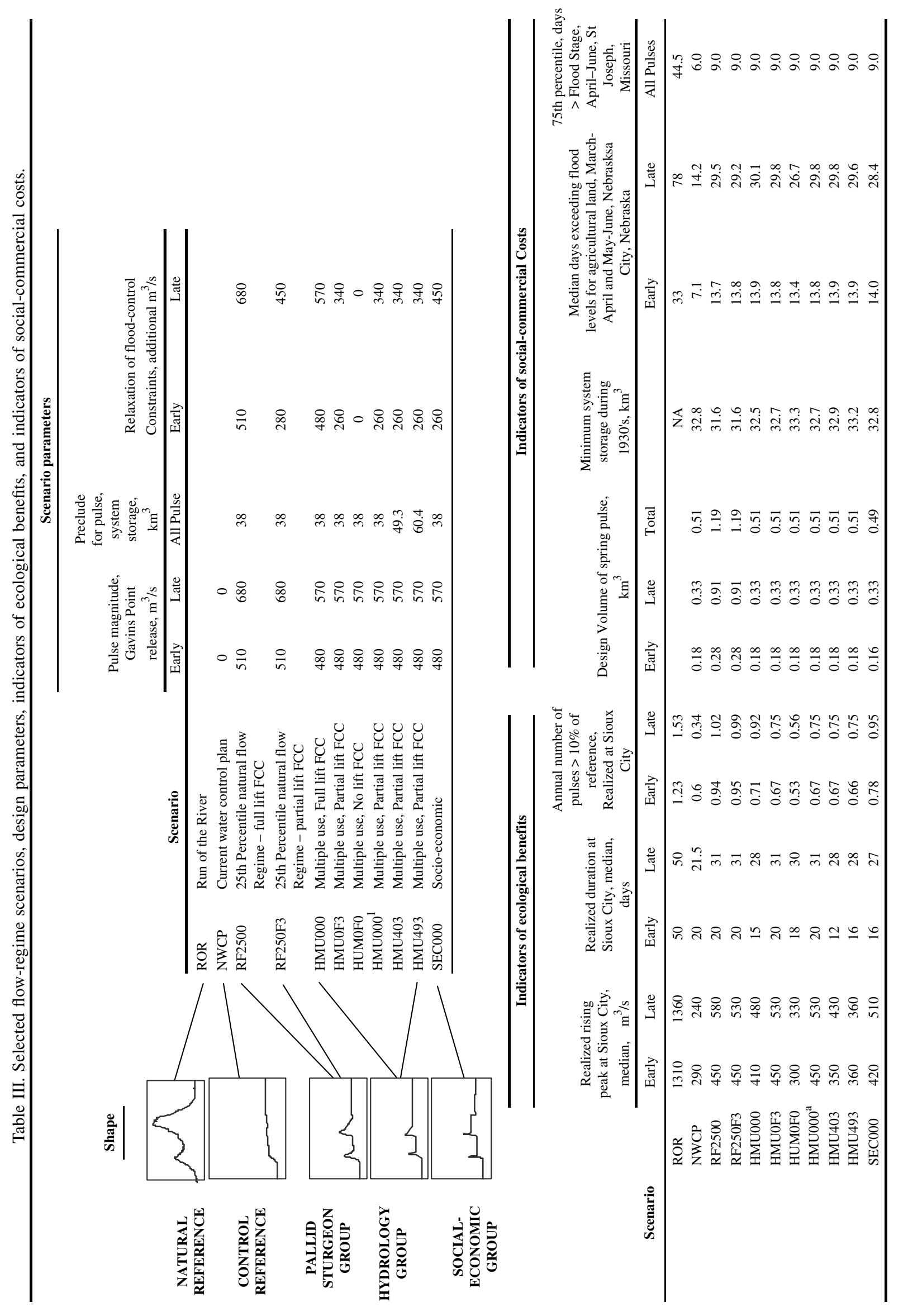


for discussion. Conceptual hydrographs included those designed from percentiles of EFCs of the reference flow regime and a variety of others that put more emphasis on avoiding costs, but still included elements of the natural flow regime (Table III). All conceptual hydrographs had two pulses separated by a low-flow period, with the second pulse declining to a low flow that was still capable of supporting navigation.

Relative performance is challenging to assess based on conceptual hydrographs alone, because actual flow releases from reservoirs have to address interannual hydroclimatic variability. Temporal variability was assessed by simulating the conceptual hydrographs in the DRM using thresholds and rules that take into account varying hydroclimatic conditions (Table III). Storage precludes account for low storage in the reservoirs during drought by limiting spring-pulse releases. Precludes stipulate an amount of storage that is necessary before a pulse can be released, and may stipulate a proportional decrease of flow for the pulse based on storage on certain dates during the year (U.S. Army Corps of Engineers, 2006). The rules also account for high-flow years by using flood-control constraints. Flood-control constraints limit releases of pulses during wet periods by setting maximum target flows at downstream locations in the mainstem. Flood control constraints are the flows that turn off upstream releases, so they must be relaxed (increased) in many years to allow pulses to occur.

The conceptual hydrographs, storage precludes, and flood-control constraints for selected designs were formalized as rules in the Corps' DRM to create alternative flow regimes (A to B, Figure 2). Each flow regime was developed by modelling the same 100 years of hydroclimatic inputs, resulting in flow-regime datasets that can be compared to one another.

Performance metrics. In past analyses of LMOR alternative flow regimes, various models have been used to assess performance in terms of economic revenues (including navigation, hydropower, water supply, and flood-control benefits) and relative environmental performance (including fish production, physical habitat availability, and wildlife resources) (U.S. Army Corps of Engineers, 2004b). Whereas these environmental models provide some quantifiable basis for understanding ecological responses, they do not directly address specific questions relating to pallid sturgeon reproduction and survival. Lacking these response functions, we based assessments on how closely an alternative design reproduced EFCs in the reference-flow regime. Hence, indicators of ecological benefits specific to sturgeon reproduction and survival were calculated as the relative rising-peak discharge for pulses, the duration of pulses, and the number of early and late pulses achieved per year. These values were calculated from realizations of the DRM for the selected designs (Table III).

Indicators of social-economic costs were developed for the volume of water used in the spring pulses, and in terms of the numbers of days at or over thresholds of downstream flooding. Indicators for water use were the total amount of water used in the conceptual springpulse designs and the minimum storage levels attained during the drought of the 1930s calculated from DRM simulations (Table III).

During the Plenary Group deliberations, representatives of the downstream agricultural community expressed dissatisfaction with the existing flood-control benefits models used on the LMOR for calculating costs of flooding. Instead of relying on models that calculate flood damages when flows overtop the bank or levee, they indicated that substantial flood damage could accrue when flows in the main channel reached stages that interfered with flow through flap gates on culverts that drain fields on the landward side of the levees. Unimpeded drainage from agricultural fields was considered particularly important during the spring and early summer when fields are being prepared for planting and locally heavy rains are likely. Flap gates between Omaha, Nebraska, and St Joseph, Missouri, were considered especially vulnerable to flow blockage because of channel aggradation in that segment (U.S. Army Corps of Engineers, 2004a). Lacking comprehensive interior-drainage hydrologic models for the entire LMOR valley bottom, Plenary Group participants adopted specific locations and discharges as indicators of flood effects on low-lying agricultural lands (Table IV). The flow exceedances of these flooding thresholds are not uniform along the river, indicating variability in the design of drainage projects. For

Table IV. Discharges, stages, and exceedances at flows that indicate flood damage, Lower Missouri River.

\begin{tabular}{|c|c|c|c|c|}
\hline Gaging station & $\begin{array}{l}\text { Discharge, at } \\
\text { NWS flood } \\
\text { stage, } \mathrm{m}^{3} / \mathrm{s}\end{array}$ & $\begin{array}{l}\text { Local flood stage, } \\
\text { metre above } \\
\text { arbitrary datum }\end{array}$ & $\begin{array}{c}\text { Negotiated } \\
\text { limiting } \\
\text { discharge, } \mathrm{m}^{3} / \mathrm{s}\end{array}$ & $\begin{array}{l}\text { Exceedance of } \\
\text { negotiated } \\
\text { limiting } \\
\text { discharge, } \%\end{array}$ \\
\hline Sioux City, Iowa & 3110 & $11 \cdot 0$ & & \\
\hline Omaha, Nebraska & 3790 & $8 \cdot 8$ & & \\
\hline Nebraska City, Nebraska & 2350 & $5 \cdot 5$ & 1330 & $22 \cdot 6$ \\
\hline St Joseph, Missouri & 2520 & $5 \cdot 2$ & 1560 & $20 \cdot 9$ \\
\hline Kansas City, Missouri & 5660 & $9 \cdot 8$ & 1870 & $21 \cdot 3$ \\
\hline Boonville, Missouri & 4470 & $6 \cdot 4$ & 2430 & $16 \cdot 8$ \\
\hline Hermann, Missouri & 5430 & $6 \cdot 4$ & 3110 & $17 \cdot 9$ \\
\hline
\end{tabular}


this analysis we chose stage thresholds at Nebraska City, Nebraska for March-April and May-June.

Discharges at U.S. National Weather Service flood stages also were calculated using stage-discharge curves at the main streamflow-gaging stations on the LMOR. In the USA, flood stage is defined as a gage height above which a rising water level creates a hazard to lives, property, or commerce (National Weather Service, 2006), so flood stage at these locations provides another, less conservative indicator of costs potentially associated with spring pulses. However, like flap-gate elevations, flood stages are specific to conditions at given locations and cannot necessarily be interpolated along the river with confidence. For this analysis, we chose flood stages at St Joseph, Missouri during April-June (Table IV).

We relied on graphical methods to communicate analysis results to Plenary Group participants. Box plots were used to show the distributions of EFCs and social-economic indicators (Figures 9-13). Graphical methods were supplemented with non-parametric, Kolmogorov-Smirnov goodness-of-fit statistics comparing cumulative distribution functions to the reference hydrograph and to each other (supporting materials for this article in Jacobson, 2008). These comparisons indicate how distributions of ecological and social-economic indicators vary by flow design and within the framework of 100 years of hydroclimatic variability. Flow regimes that are determined to be significantly different by this test are not necessarily ecologically different, because the Kolmogorov-Smirnov test assesses similarity of the cumulative distributions of the variables, but does not address whether specific parts of the distribution (say, wet or dry extremes) are similar; the wet or dry tails of the distributions may have important ecological functions.

\section{RESULTS OF ALTERNATIVES ANALYSIS}

Results of the design alternatives analysis are reported here and in supporting data in Jacobson (2008). Distributions of early-pulse relative rising peak magnitudes vary little among design-flow regimes, but all designs are significantly different from the ROR [Figure 9(A); (Jacobson, 2008; Table I, $p<0.001$ )]. The designs based on $25 \%$ of the reference hydrograph (RF series) have somewhat lower medians and less range than the NWCP (2004 water-control plan) and the HMU (multiple-use series) and SEC (social-economic series). The latepulse magnitudes show a similar pattern except that the NWCP has a significantly lower median than the ROR and the other designs [Figure 9(B); (Jacobson, 2008; Table II, $p<0.001)]$. The RF25000 alternative has a somewhat higher median than the other design alternatives.

The distributions of early-pulse durations show less variation than the peak magnitudes (Figure 10(A)). The ROR flow regime has only slightly longer durations than the design alternatives and the NWCP, in part
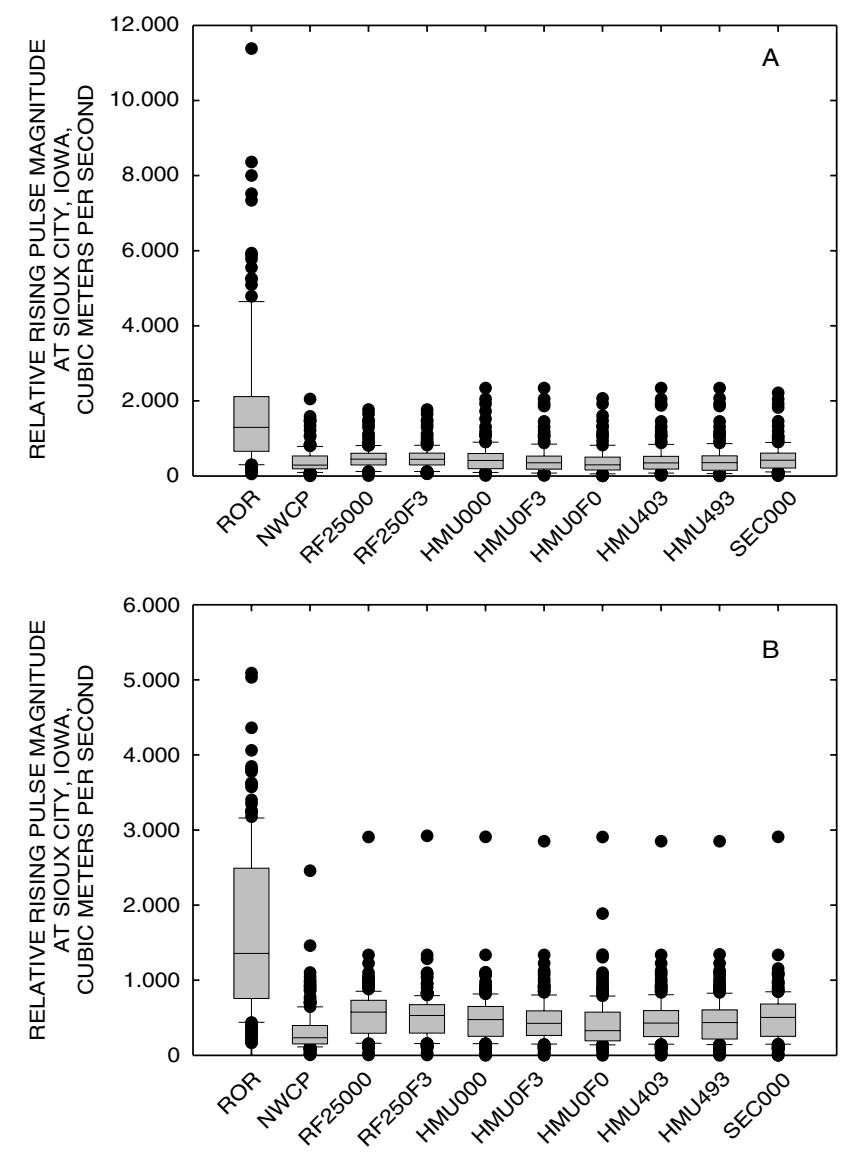

Figure 9. Box plots showing the distributions of magnitudes of relative rising peaks of pulses extracted from 100 years of modelled flows. (A) Early peaks, March-April. (B) Late peaks, May-June. Abbreviations for flow regime scenarios are presented in Table III.

because of the long steady pulses that result from releases for navigation. The distributions of late-pulse durations show more marked variation of the ROR and NWCP flow regimes compared to the others, but none of the designed alternatives differ significantly from each other [Figure 10(B), (Jacobson, 2008; Table IV)].

Social-economic costs indicated by days per year of flooding of low-lying agricultural land showed similar patterns [Figure 11, (Jacobson, 2008; Tables V, VI)]: costs of the ROR was significantly different and higher than other regimes for early and late pulses $(p<0.001$, [Jacobson, 2008; Tables V, VI]). The days of flooding for the early pulse for the NWCP did not differ significantly from any of the design alternatives. Days of flooding of low-lying land during the late pulse were significantly less for the NWCP compared to most other designs [0.00 $<p<0.05$, (Jacobson, 2008; Tables V, VI)]. Costs associated with days over flood stage at St Joseph's, Missouri, are indicated in Figure 12 and Jacobson (2008; Table VIII). The ROR flow regime is significantly different from the design regimes $(p<$ 0.001 ), but none of the design-flow regimes are significantly different from each other.

Social-economic costs associated with water used by spring flow pulses are indicated by the distributions of monthly minimum system storage [Figure 13, (Jacobson, 

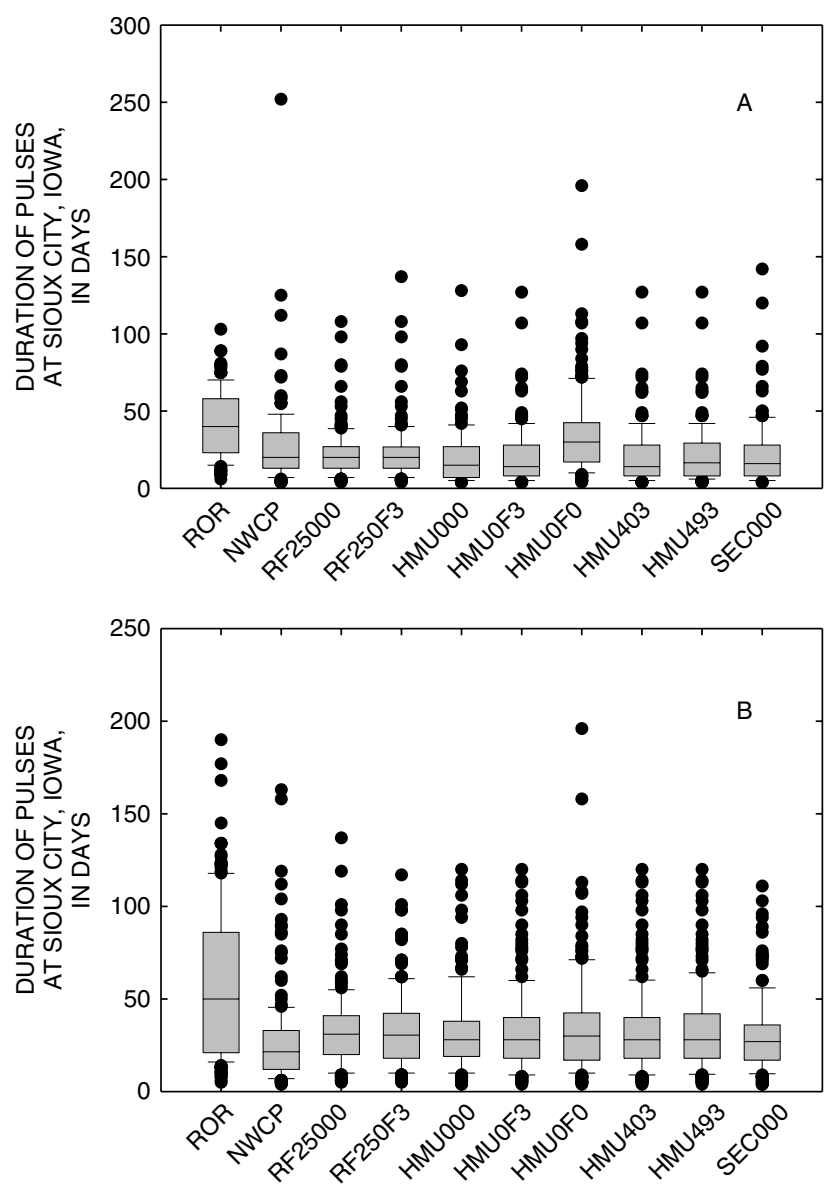

Figure 10. Box plots showing the distributions of durations of pulses extracted from 100 years of modelled flows. (A) Early pulses, March-April. (B) Late peaks, May-June. Abbreviations for flow-regime scenarios are presented in Table III.

2008; Table VIII)]. No system storage data are applicable for the reference flow regime since the ROR model is calculated with the reservoirs completely full. Although there is little apparent variation in storage distributions among the flow designs, the RF distributions have slightly higher medians than the others and are significantly different from two of the HMU series.

Some insight into trade-offs between presumed ecological benefits and social-economic costs can be gained through bivariate plots of medians of the selected variables (Figure 14; Table III). In this analysis, the values are normalized so the highest benefit (or lowest cost) is 1.0. There is no guarantee that the designs selected by stakeholders represent the universe of all possible solutions or that they define an envelope of non-inferior solutions. Nevertheless, the trade-offs between pairs of objectives indicate the relative gains and losses moving from one design to another.

The general form of these trade-off curves (Figure 14) is concave upward, indicating inefficient solutions in which there is a steep trade-off between ecological and social-economic objectives. The exception is system storage (Figure 14(A)) which appears relatively insensitive to ecosystem objectives: early and late relative rising pulse peaks can be increased to nearly $80 \%$ of that
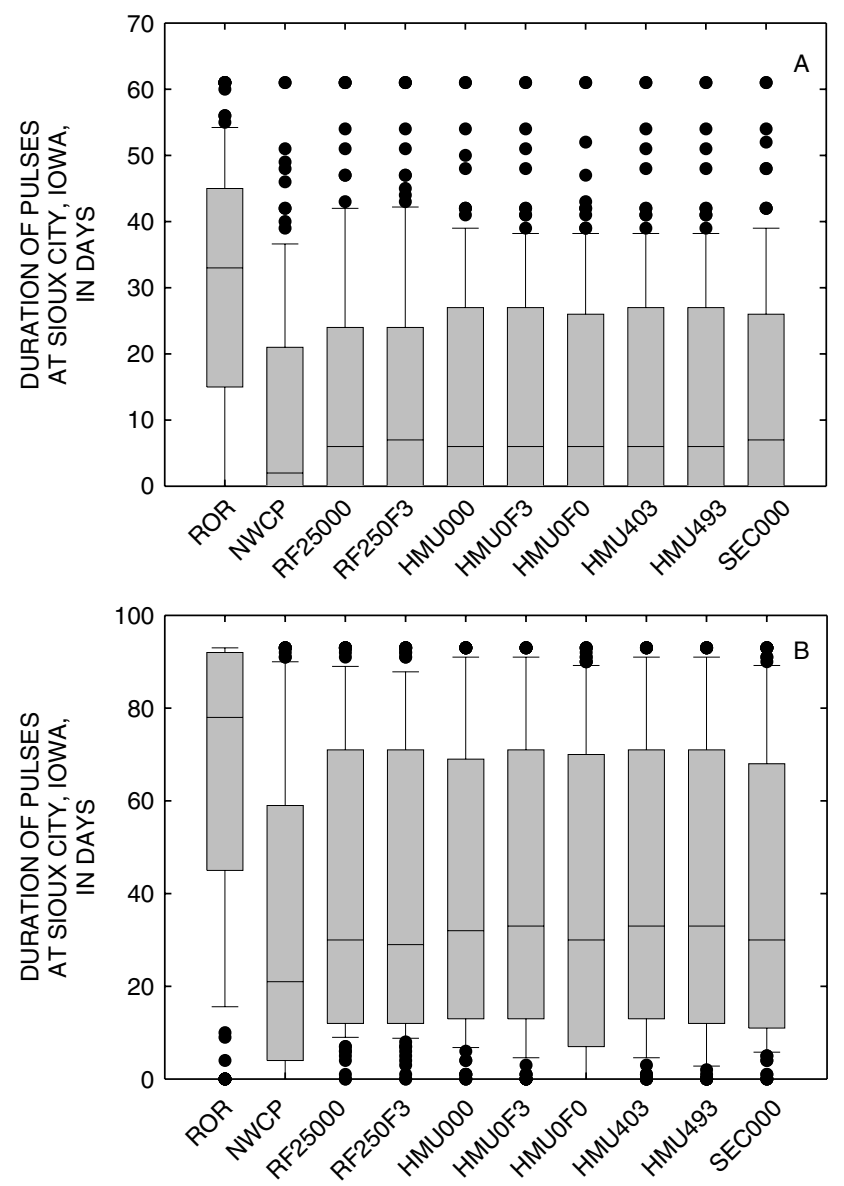

Figure 11. Box plots showing the distributions of durations that flow would interfere with drainage of low-lying agricultural land through flap gates extracted from 100 years of modelled flows. (A) Early pulses, March-April. (B) Late peaks, May-June. Abbreviations for flow-regime scenarios are presented in Table III.

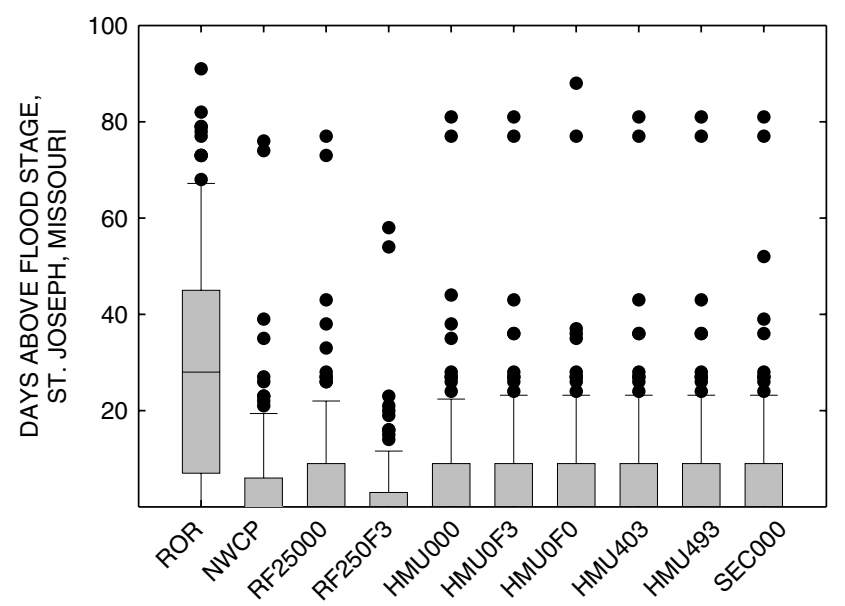

Figure 12. Box plots showing the distributions of durations days above National Weather Service flood stage at St Joseph, Missouri, April-June. Abbreviations for flow-regime scenarios are presented in Table III.

possible under the ROR while decreasing system storage only $10 \%$ from that possible under the NWCP. Another observation evident from the bivariate trade-offs is that relatively modest increases in presumed ecological benefits entail substantial decreases in social-economic benefits if the social-economic benefits are measured in 


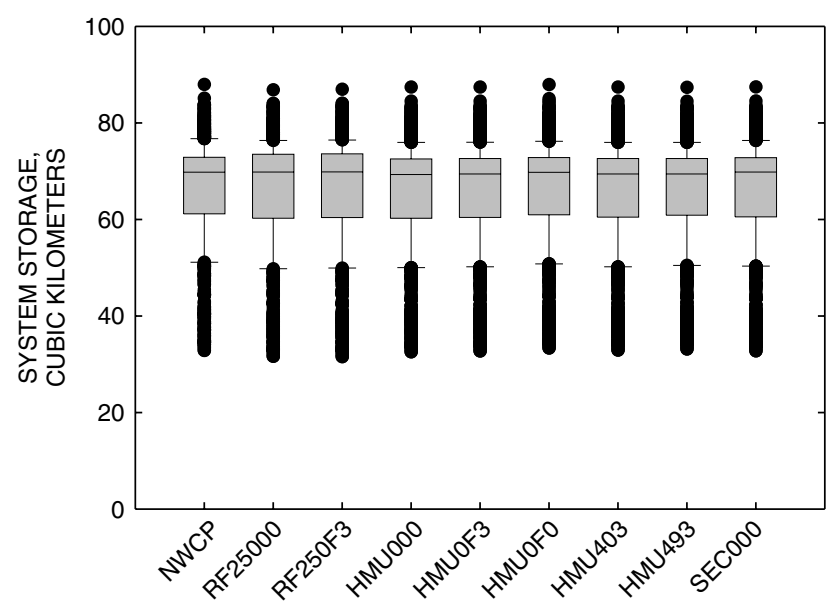

Figure 13. Box plots showing the distributions of storage levels in reservoir system. Abbreviations for flow-regime scenarios are presented in Table III.

terms of days of flooding of low-lying agricultural lands. The costs of the designs investigated, however, vary little among themselves while the ecological benefits vary substantially. That is, once the investment is made in diminished social-economic benefits moving from the NWCP to the alternative designs (Figure 14(A), (B), (C)), substantial ecological benefits (inferred from degree of similarity to the ROR) can be gained without further loss of social-economic benefits.

\section{DISCUSSION}

Decision making with inadequate information is not uncommon in river management (Walters, 1997; Tharme, 2003). Whereas the LMOR flow-regime design process had the benefit of strong, technical modelling support, it was challenged by a short timeframe and substantive gaps in critical biological information. Notwithstanding the scientific uncertainties, the process went forward in an attempt to use the best available information to inform naturalization of the flow regime.

Ultimately, the participants in the LMOR Plenary Group Process failed to reach consensus on design of spring pulses. There were probably many social, economic, political, and technical reasons that stakeholders failed to reach full consensus. Among the technical reasons, it was clear that reasoning from the natural flow regime did not provide sufficiently quantitative predictions of the ability of spring pulses to improve reproduction and survival of the pallid sturgeon. As one of the stakeholders noted: 'To date there is little information to support the hypothesis that the native fishes of the Missouri River, including the endangered pallid sturgeon, are cued to spawn by flood pulses'. (Jorgensen, 2006). In terms of the conceptual model in Figure 3, stakeholders were unwilling to accept the inference that the alterations to the flow regime measurable in Tier 1 would propagate effectively to the desired biological result in Tier 3 .
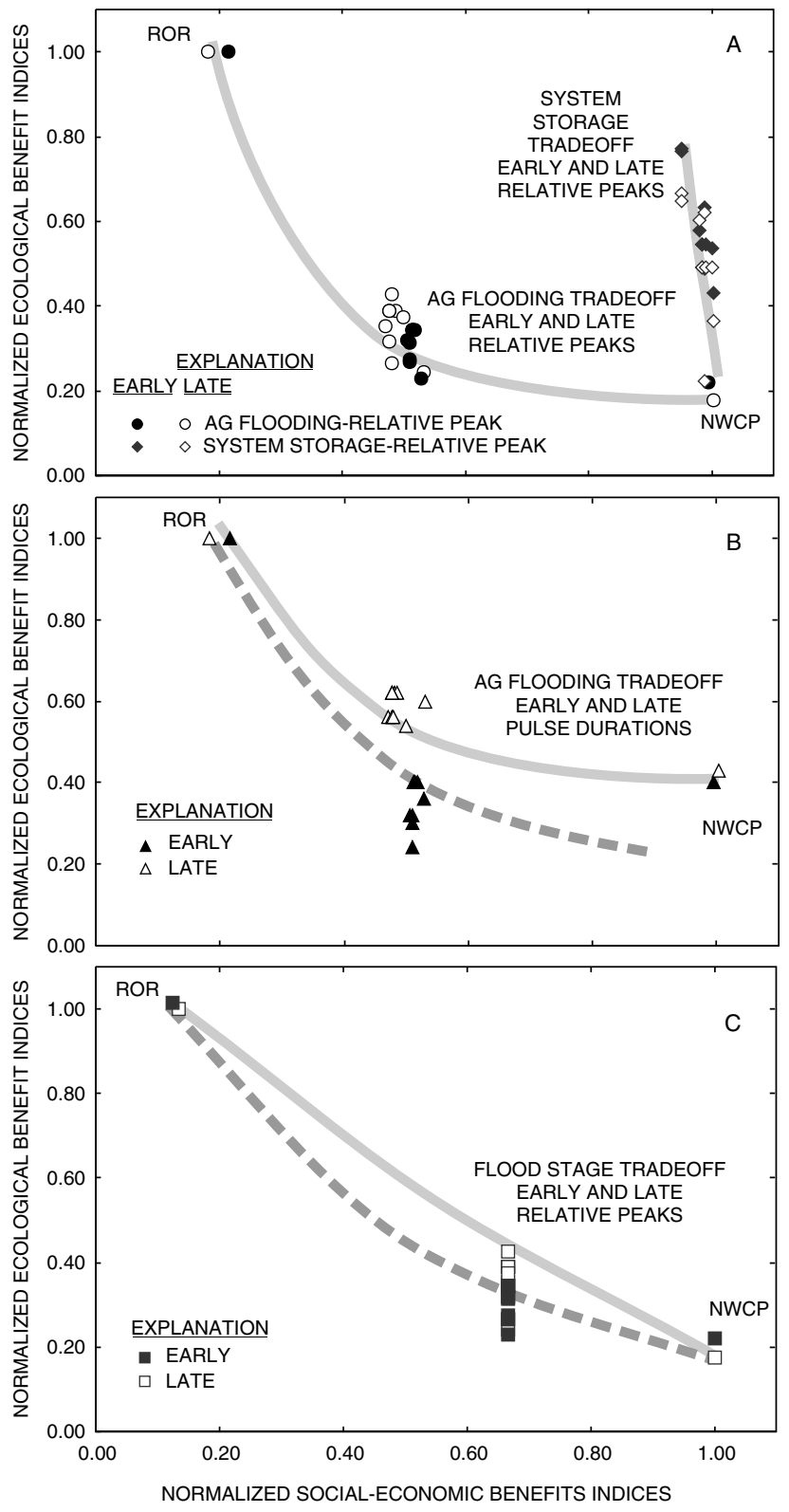

Figure 14. Simplified trade-off curves for normalized ecological benefits and social-economic costs, among the current water control plan (NWCP), the reference flow regime (ROR), and design alternatives. (A) Magnitude of relative peaks plotted with days of flooding of low-lying agricultural land (at Nebraska City, Nebraska) and system storage. (B) Duration of pulses with days of flooding of low-lying agricultural lands. (C) Magnitude of relative peaks plotted with days exceeding flood stage at St Joseph, Missouri.

At the same time, stakeholders had available to them very precise numbers defining the loss of socialeconomic benefits (left side of Figure 3), from which they were willing to infer direct financial losses. Moreover, simple trade-off analysis indicated that substantial proportional losses of many social-economic benefits would be incurred before inferred ecological benefits would increase (Figure 14(A), (B), (C)).

\section{Design considerations}

The 2005 design approach on the Missouri River was strongly constrained by a framework of river laws, the 
U.S. Endangered Species Act, and institutional missions and authorities of participating agencies. Unlike waterregulation concepts like the Water Framework Directive (European Commission, 2000), US regulations lack emphasis on holistic measures of biological integrity (Adler, 2003). Moreover, Plenary Group stakeholders showed little interest in pursuing consideration of other ecosystem services that might be related to naturalized flow regimes. Hence, the design was narrowly focussed on issues related to the endangered species. Although the Endangered Species Act has been frequently criticized for its narrow focus, it has also been recognized as the dominant law in the USA for species conservation (Karr, 1990; Rohlf, 1991; Clark et al., 2002), and the LMOR experience is therefore not unusual.

Without the ability to quantify sturgeon reproductive responses to flow pulses, the design process turned to the natural flow regime for guidance in deriving design parameters and evaluating relative performance. Designs that extracted percentiles of EFCs from the natural flow regime were similar to the 'flow translucency' approach in using the natural flow regime as a template for a design flow regime (Gippel, 2001). Design from the natural flow regime also implicitly incorporates aspects of a holistic, 'top-down' approach which assumes that flow regimes closer to the natural flow regime would have greater ecological benefits (Arthington, 1998b). That is, if the flow regime was restored, other ecological functions would necessarily follow. Two implicit assumptions of holistic approaches are (1) flow regime is the master variable, and other factors like sediment, temperature, and water quality do not vary independently to a substantive degree, and (2) ecological responses to flow components are linear, non-threshold functions (Poff et al., 1997; Stewardson and Gippel, 2003). Moreover, designs based on EFCs in the reference flow regime assume that the correct EFCs have been identified. In the case of designs for pulses that are intended to achieve a specific reproductive response, this assumption is critical.

The design process also used elements of a 'bottomup' or 'building block' approach (Arthington, 1998b; King et al., 2003) in assembling pulses to peak at particular times to match the best available information on water temperature and photoperiod constraints on sturgeon spawning. Adjusting the late pulse to an earlier time during the year was inconsistent with the natural flow regime, but was intended to build a composite flow regime from elements needed for reproduction of both shorebirds and sturgeon. The most fundamental example of the building block approach was using the navigation season hydrograph as the foundation for flow-regime designs.

Initially, the LMOR process emphasized change in flow management to benefit one species, rather than designing for holistic benefits to the ecosystem (Richter et al., 2003, 2006; Tharme, 2003). Lacking the specific information to design for pallid sturgeon reproduction and survival, however, forced the design process to rely on the natural flow regime, an approach that may have ancillary benefits for other species.

\section{Information and process needs}

The design process focussed attention on unknowns in the Missouri River ecosystem and on challenges to collaborative decision making. In particular, it underscored the need to develop more fundamental information on pallid sturgeon reproductive requirements and responses to flow modifications, and to develop a modelling process that forecasts biological responses in ways that would be considered credible and useful by stakeholders.

Improving response functions. Modifications of flow regimes on large, multipurpose river systems necessarily involve trade-offs, with some services increasing at the expense of others to maximize system benefits. In a decision-making context where stakeholders can evaluate some social-economic benefits and costs very precisely (for example, hydropower or flood-control benefits), there is an expectation that ecological benefits and cost estimates will be similarly precise. The design process on the LMOR indicated that many stakeholders were uncomfortable with prospects of incurring losses of system benefits (real or perceived) without assurance that prospects for the pallid sturgeon would improve. The assumption that a naturalized flow regime would result in increased sturgeon reproduction was ultimately inadequate.

In recognition of these knowledge gaps, the Plenary Group process also generated hypotheses that became the framework for an adaptive management monitoring plan. The monitoring and assessment plan includes extensive evaluations of sturgeon movements in response to flow pulses, physiological monitoring of sturgeon populations, and assessments of habitat use, availability, and geomorphic change (Korschgen, 2007). The assessment began in 2005 and is intended to continue over the next 5-10 years, comparing years with and without flow pulses. Similar field-based assessments were implemented in 2005 to document effects on drainage and flooding of low-lying agricultural lands.

Improving assessment and modelling capability. The framework used by the LMOR design process was similar to that of the instream flow incremental methodology (IFIM) (Bovee et al., 1998) in that it included consideration of flow alternatives using flow models and ecological response functions in a negotiating framework. The ability to combine hydroclimatic time series with alternative flow-regulation rules is a critical part of the decision making process (Figure 2). The LMOR process benefited from existence of a daily hydrologic routing model, which provided a means to assess relative flow-regime performance over 100 years of climatic variability.

In presenting model results to stakeholders we tried to emphasize three contextual themes. 
- Two reference conditions. Both the ROR and the NWCP were presented as references so stakeholders could see how much a particular design performed as a change from current conditions or as change toward an ideal, historical condition.

- Inherent temporal variability. Rather than focussing on mean or median statistics, when possible we presented graphics and statistics that illustrated populations of hydrologic variables resulting from hydroclimatic variability. Box plots seemed to be an effective means of communicating within- and among-design variability (Figures 9-13).

- Spatial variability. We emphasized that along the $1300 \mathrm{~km}$ of the LMOR, spatial variability in channel morphology and tributary inputs is expected to alter the ecological benefits and social-economic costs associated with redesigned flow regimes. Appreciation of spatial variability of the river added new questions to the process, including how much of the river would be affected appreciably by pulsed flows, and whether those segments of the river had specific importance to pallid sturgeon reproduction and survival.

The LMOR design process also demonstrated the importance of modelling in a collaborative, stakeholderdriven process. Stakeholders were able to design alternative conceptual hydrographs and submit them to the DRM to produce modelled-flow regimes that could be used for statistical analysis or to drive other effects models. However, the modelling process lacked real-time interaction that could have provided stakeholders with the ability to explore a wider range of alternatives. The ability to run a wider range of alternative simulations would allow more complete analysis of the trade-off functions, possibly identifying more efficient solutions (Figure 14). A modelling process that allows stakeholders free rein to explore efficiently and rapidly a wide range of alternatives would better support the decision-making process.

\section{Epilogue}

Although the LMOR Plenary Group process failed to reach consensus on a design, the results were used by the U.S. Army Corps of Engineers in their implementation of a pulsed flow in spring 2006. The 2006 annual operating plan (AOP) borrowed two key concepts from the design discussions. First, the shapes of the pulses were more natural than the previous, default design (U.S. Fish and Wildlife Service, 2003), having 2-day peaks rather than 2-week plateaus, and kinked, asymmetric receding limbs (Figure 15). Second, the AOP set criteria that the second peak would occur within a window 1-19 May, with a release only after daily mean water temperature downstream of the dam had reached $16^{\circ} \mathrm{C}$ for the second time that season. The latter provision was made to assure that the second peak occurred nearsuspected pallid sturgeon spawning temperature. The designed peaks were modest with a planned increase of $340 \mathrm{~m}^{3} / \mathrm{s}$ above winter flows for the early peak (11th percentile of the reference flow regime) and a late peak of $340-450 \mathrm{~m}^{3} / \mathrm{s}$ above navigation flows $(6-10$ th percentile of the reference flow regime). Because of general drought conditions in the basin, the second peak was planned to be $340 \mathrm{~m}^{3} / \mathrm{s}$ in 2006 (Figure 15).

The actual releases were substantially different from the concept (Figure 15). The early pulse was not released because of insufficient storage in the system. Because of

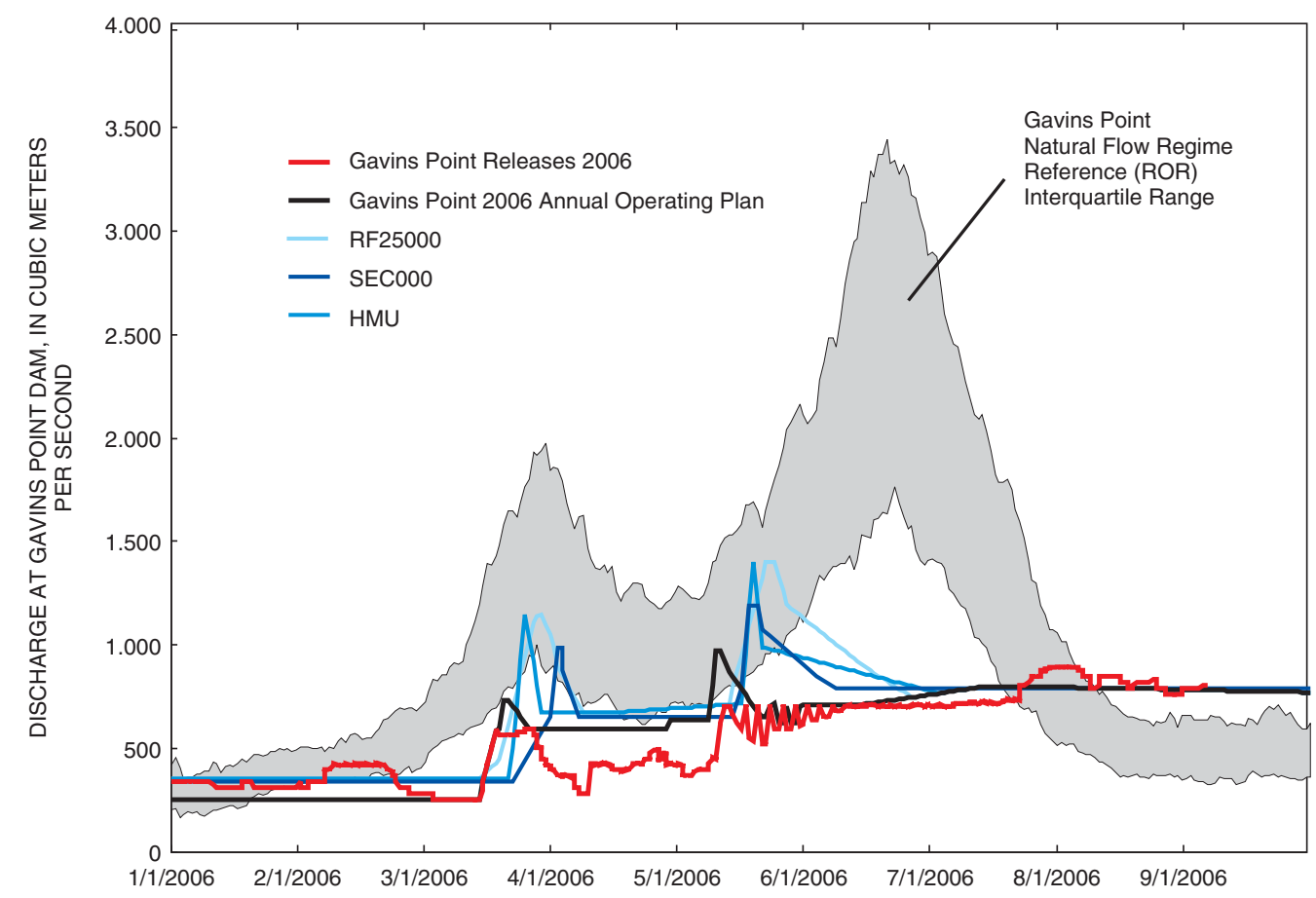

Figure 15. Comparison of planned 2006 flow modification (U.S. Army Corps of Engineers, 2006), actual 2006 discharge, interquartile range of the reference hydrograph (ROR), and three alternative design conceptual hydrographs. Descriptions of alternatives are in text. 
low-navigation traffic, flows were kept fairly low until 12 May, and then were increased by $260 \mathrm{~m}^{3} / \mathrm{s}$ (3rd percentile of the reference hydrograph) to about $715 \mathrm{~m}^{3} / \mathrm{s}$. Discharge was held near $715 \mathrm{~m}^{3} / \mathrm{s}$ for 2 days and then dropped $120 \mathrm{~m}^{3} / \mathrm{s}$ to about $595 \mathrm{~m}^{3} / \mathrm{s}$ over 3 days. After that flows were cycled 1 day up, 2 days down, from $524 \mathrm{~m}^{3} / \mathrm{s}$ to $715 \mathrm{~m}^{3} / \mathrm{s}$ until 13 June. Flow cycling was intended to keep birds from nesting at low elevations on sandbars (U.S. Army Corps of Engineers, 2006). The actual pulsed-flow modification in 2006 illustrates the practical challenges of implementing a flow-regime change within the context of highly variable hydroclimatic conditions and multiobjective and multiple-species management.

\section{SUMMARY AND CONCLUSIONS}

During the summer of 2005, a group of managers, stakeholders, and scientists met to design a naturalized flow regime for the LMOR in the USA. Decision making on the Missouri River has had to confront issues common to large rivers worldwide: to increase ecological functions while minimizing conflicts with other river services. The objective of the Missouri River process was to restore elements of natural variability specifically to support reproduction and survival of the endangered pallid sturgeon ( $S$. albus). Design was constrained by legal authorities, institutional roles, the need to avoid flooding of sandbar nesting birds, as well as by competing socialeconomic system services such as navigation, recreation, flood control, and hydropower. The Missouri River experience documents some of the practical challenges to flow naturalization on multipurpose river systems.

Specific spawning requirements for pallid sturgeon reproduction-timing, magnitude, rate of change, and sequence-are not known and depend, at least in part, on concurrent factors such as water temperature and photoperiod. Lacking specific, biologically defined design parameters, the general approach used to design alternative flow regimes was based on elements of the natural flow regime, informed by general understanding of sturgeon biology, and constrained by requirements of other species and competing uses. We used EFCs extracted from the reference natural-flow regime for two purposes. Percentiles of the EFCs were used to design a subset of spring pulses that recovered 5-50\% of the relative rising peak and duration of the natural flow regime. EFCs from the natural flow regime were also used to assess relative performance of flow regimes that were designed with less emphasis on recovering natural variability.

The design process incorporated a primary stage in which conceptual hydrographs were developed and assessed in terms of relations to the natural-flow regime, how well the pulses synchronized with water temperature and photoperiod, how much water they drafted from system storage under average conditions, and the extent to which they conflicted with other species and other system uses. The second stage accounted for hydroclimatic variation by coding the conceptual hydrographs into reservoir release rules, adding constraints for downstream flooding and low-storage precludes, and running the rules through 100 years of hydroclimatic simulation. The results of the simulations provide a consistent basis for assessing flow-regime alternatives over a broad range of conditions. The output flow regimes were then evaluated for presumed ecological benefits (based on how closely they resembled EFCs in the reference natural flow regime) and for social-economic cost indicators, including days of flooding of low-lying agricultural land, days over flood stage, and storage levels in system reservoirs. A simplified trade-off analysis indicated that more-natural pulses were associated with substantial increases in flooding of low-lying agricultural lands and small increases of days over flood stage. Reservoir system storage was not particularly sensitive to naturalization of the flow regime under the designs considered.

Our experience with flow-regime design on the LMOR emphasizes several key issues that are probably generic to ecologically based river management. First, design based on the natural flow regime is compelling for its value in addressing holistic ecological concerns and for providing design guidance in the absence of specific biological requirements. However, stakeholders who could potentially lose benefits would not accept performance relative to the natural flow regime as a sufficient indicator of ecological benefit. Stakeholders desired proof of ecological performance commensurate with the certainty of their losses. Second, the ability to simulate the results of alternative flow regimes under a representative range of hydroclimatic conditions is essential for assessments in realistic context. In a collaborative, stakeholder-driven environment, simulations are most effective when they can be used interactively to explore a wide range of possibilities. Third, a flow regime design is only a template. Implementation under real-world conditions may diverge substantially from the design intent in order to reconcile competing system benefits.

Finally although this particular negotiation failed to reach a consensus, the process was successful in developing a design approach, focussing science on key knowledge gaps, ultimately influencing flow management, and demonstrating the potential for collaborations among scientists, stakeholders, and managers in decision making. Rogers (2006) has asserted that the key challenge in river management is to develop collective understanding among scientists, citizens, and managers; experiences on other large river restoration projects confirm the need to invest in collective understanding (Buijse et al., 2002). The LMOR example supports this idea and the conclusion that collective understanding and fundamental science are both necessary conditions for progress in flow-regime management; neither alone appears to be sufficient.

\section{ACKNOWLEDGEMENTS}

We are indebted to the members of the 2005 Missouri River Plenary Group for the opportunity to participate 
in the design process. We especially acknowledge daily routing model output files that were provided by Roy McAllister and Michael Swenson, U.S. Army Corps of Engineers, Omaha, Nebraska.

\section{REFERENCES}

Adler RW. 2003. The two lost books in the water quality trilogy: the elusive objectives of physical and biological integrity. Environmental Law 33: 29-77.

Arthington AA. 1998a. Comparative Evaluation of Environmental Flow Assessment Techniques: Best Practice Framework. Land and Water Resources Research and Development Corporation, Occasional Paper 25/98: Canberra; 26.

Arthington AA. 1998b. Comparative Evaluation of Environmental Flow Assessment Techniques: Review of Holistic Methodologies. Land and Water Resources Research and Development Corporation, Occasional Paper 26/98: Canberra; 46.

Arthington AA, Bunn SE, Poff NL, Naiman RJ. 2006. The challenge of providing environmental flow rules to sustain river ecosystems. Ecological Applications 16: 1311-1318.

Barton GJ, McDonald RR, Nelson JM, Dinehart RL. 2005. Simulation of Flow and Sediment Mobility Using a Multidimensional Flow Model for the White Sturgeon Critical-Habitat Reach, Kootenai River near Bonners Ferry, Idaho. Scientific Investigations Report 2005-5230. U.S. Geological Survey: Reston, VA; 54.

Bemis WE, Kynard B. 1997. Sturgeon rivers: an introduction to acipsenseriform biogeography and life history. Environmental Biology of Fishes 48: 167-183.

Berenbrock C, Bennet JP. 2005. Simulation of Flow and Sediment Transport in the White Sturgeon Spawning Habitat of the Kootenai River near Bonners Ferry, Idaho. Scientific Investigations Report 20055173. U.S. Geological Survey: Reston, VA; 72.

Blevins DW. 2006. The Response of Suspended Sediment, Turbidity, and Velocity to Historical Alterations of the Missouri River, Circular 1301. U.S. Geological Survey: Reston, VA; 8. http://pubs.usgs.gov/circ/2006/1301/ [accessed 31 March 2008].

Bovee KD, Lamb BL, Bartholow JM, Stalnaker CB, Taylor J, Henriksen J. 1998. Stream Habitat Analysis Using the Instream Flow Incremental Methodology. Information and Technology Report USGS/BRD1998-0004. U.S. Geological Survey: Reston, VA; 131.

Buckley J, Kynard B. 1985. Habitat and behavior of pre-spawning and spawning shortnose sturgeon, Acipenser brevirostrum, in the Connecticut River. In North American Sturgeons-Biology and Aquaculture Potential, Binkowski FP, Doroshov SI (eds). Junk Publishers: Dordrecht; 111-117.

Buijse AD, Coops H, Staras M, Jans LH, Van Geest GJ, Grift RE, Ibelings BW, Oosterberg W, Roozen FCJM. 2002. Restoration strategies for river floodplains along large lowland rivers in Europe. Freshwater Biology 47: 889-907.

Bunn SE, Arthington AA. 2002. Basic prinicples and ecological consequences of altered flow regimes for aquatic biodiversity. Environmental Management 30: 492-507.

Burch RM, Binkowski FP. 2002. Spawning behavior of lake sturgeon (Acipenser fulvescens). Journal of Applied Ichthyology 18: 570-579.

Chapman FA, Carr SH. 1995. Implications of early life stages in the natural history of the Gulf of Mexico sturgeon, Acipenser oxyrinchus de sotoi. Environmental Biology of Fishes 43: 407-413.

Christenson LM. 1975. The shovelnose sturgeon, Scaphirhynchus platorynchus (Rafinesque) in the Red Cedar-Chippewa River system. Research Report 82. Wisconsin Department of Natural Resources: Madison, WI; 23.

Clark JA, Hoekstra JM, Boersma PD, Kareiva P. 2002. Improving U.S. endangered species act recovery plans: key findings and recommendations of the SCB recovery plan project. Conservation Biology 16: 1510-1519.

Coutant CC. 2004. A riparian habitat hypothesis for successful reproduction of white sturgeon. Review in Fisheries Science 12: 23-73.

De Vlaming VL. 1972. Environmental control of teleost reproductive cycles: a brief review. Journal of Fish Biology 4: 131-140.

Doroshov SI. 1985. Biology and culture of sturgeon Acipenseriformes. In Recent Advances in Aquaculture, Vol. 2, Muir JF, Roberts RJ (eds). Westview Press: Boulder, CO; 251-274.

Doroshov SI, Moberg GP, Eenennaam JP. 1997. Observations on the reproductive cycle of cultured white sturgeon, Acipenser transmontanus. Environmental Biology of Fishes 48: 265-278.
Dryer MP, Sandvol AJ. 1993. Recovery Plan for the Pallid Sturgeon (Scaphirhynchus Albus). U.S. Fish and Wildlife Service: Bismarck, ND; 55.

Elser AA, McFarland RC, Schwehr D. 1977. The effect of altered stream flow on fish in the Yellowstone and Tongue Rivers, MT, Yellowstone Impact Study. Technical Report 8. Montana Department of Natural Resources and Conservation: Helena, MT; 180.

European Commission. 2000. Directive 2000/60/EC of the European Parliament and of the Council of 23rd October 2000 establishing a framework for Community action in the field of water policy. Official Journal of the European Communities 22 December 2000 L 327, 72.

Ferrell J. 1996. Soundings-100 Years of the Missouri River Navigation Project. U.S. Army Corps of Engineers: Omaha, NE; 171.

Funk JL, Robinson JW. 1974. Changes in the Channel of the Lower Missouri River and Effects on Fish and Wildlife. Missouri Department of Conservation: Jefferson City, MO; 52.

Galat DL, Lipkin R. 2000. Restoring ecological integrity of great rivers: historical hydrographs aid in defining reference conditions for the Missouri River. Hydrobiologia 422: 29-48.

Galat DL, Berry CR Jr, Peters EJ, White RG. 2005a. Missouri river basin. In Rivers of North America, Benke AC, Cushing CE (eds). Elsevier: Oxford; 427-480.

Galat DL, Berry CR, Gardner WM, Hendrickson JC, Mestl GE, Power GJ, Stone C, Winston MR. 2005b. Spatiotemporal patterns and changes in Missouri River fishes. In Historical Changes in Large River Fish Assemblages of the Americas, Rinne JN, Hughes RM, Calamusso R (eds). American Fisheries Society, Symposium 45: Bethesda, MD; 249-291.

Gippel CJ. 2001. Australia's environmental flow initiative: filling some knowledge gaps and exposing others. Water Science and Technology 43: $73-88$.

Gore JA, Shields FD Jr. 1995. Can large rivers be restored? Bioscience 45: $142-152$.

Grant GE, Schmidt JC, Lewis SL. 2003. A geological framework for interpreting downstream effects of dams on rivers. In A Peculiar River-Geology, Geomorphology, and Hydrology of the Deschutes River, Oregon, O'Connor JE, Grant GE (eds). American Geophysical Union: Washington, DC; 209-225.

Harwell MA, Myers V, Young T, Bartuska A, Gassman N, Gentile JH, Harwell CC, Appelbaum S, Barko J, Causey B, Johnson CD, McLean A, Smola R, Templet P, Tosini S. 1999. A framework for an ecosystem integrity report card. Bioscience 49: 543-556.

Hay CH. 2006. Fish and Invertebrate Abundance in Relation to Abiotic Factors in the Missouri River. University of Nebraska-Lincoln: Lincoln, NE; 208.

Helms DR. 1974. Age and growth of shovelnose sturgeon, Scaphirhynchus platorynchus (Rafinesque) in the Mississippi River. Proceedings of the Iowa Academy of Science 81: 73-75.

Hesse LW. 1987. Taming the wild Missouri River-What has it cost? Fisheries 12: 2-9.

Hesse LW, Sheets W. 1993. The Missouri River hydrosystem. Fisheries 18: $5-14$.

Hesse LW, Schmulbach JC, Carr JM, Keenlyne KD, Unkenholz DG, Robinson JW, Mestl GE. 1989. Missouri River fishery resources in relation to past, present, and future stresses. In Proceedings of the International Large River Symposium, Dodge DP (ed.). Canadian Special Publication of Fisheries and Aquatic Sciences: Ottawa; 353-371.

Hillman M, Brierley G. 2002. Information needs for environmental-flow allocation: a case study from the Lachlan River, New South Wales, Australia. Annals of the Association of American Geographers 92: $617-630$.

Horowitz AJ. 2003. An evaluation of sediment rating curves for estimating suspended sediment concentrations for subsequent flux calculations. Hydrological Processes 17: 3387-3409.

Hurley ST. 1983. Habitat associations and movements of shovelnose sturgeon in Pool 13 of the upper Mississippi River. MS thesis, Iowa State University, Ames, 82.

Jacobson RB. 2008. Analysis of Pulsed Flow Modification Alternatives, Lower Missouri River, 2005. Open-File Report 2008-1113. U.S. Geological Survey: Reston, VA; 14. http://pubs.usgs.gov/of/2008/1113 [accessed 31 March 2008].

Jacobson RB, Galat DL. 2006. Flow and form in rehabilitation of large-river ecosystems: an example from the Lower Missouri River. Geomorphology 77: 249-269.

Jorgensen DG. 2006. Anthropogenic Changes in the Lower Missouri River Basin, their Effects on Pallid Sturgeon, and Management Implications. Missouri River Technical Committee of the Siouxland Chamber of Commerce: Sioux City, IA; 51. 
Junk WJ, Bayley PB, Sparks RE. 1989. The flood pulse concept in river-floodplain systems. Canadian Special Publication Fisheries and Aquatic Sciences 106: 110-127.

Karr JR. 1990. Biological integrity and the goal of environmental legislation: lessons for conservation biology. Conservation Biology 4: 244-250.

Keenlyne KD. 1997. Life history and status of the shovelnose sturgeon, Scaphirhynchus platorynchus. Environmental Biology of Fishes 48: 291-298.

Keenlyne KD, Jenkins LG. 1993. Age at sexual maturity of the pallid sturgeon. Transactions of the American Fisheries Society 122: 393-396.

Keown MP, Dardeau EA Jr, Causey EM. 1986. Historic trends in the sediment flow regime of the Mississippi River. Water Resources Research 22: 1555-1564.

King J, Brown C, Sabet H. 2003. A scenario-based holistic approach to environmental flow assessments for rivers. River Research and Applications 19: 619-639.

Korschgen CE (ed.). 2007. Factors Affecting the Reproduction, Recruitment, Habitat, and Population Dynamics of Pallid Sturgeon and Shovelnose Sturgeon in the Missouri River. Open-File Report 2007-1262. U.S. Geological Survey: Reston, VA; 280. http://pubs.usgs.gov/circ/2007/1315/ [accessed 31 March 2008].

Kynard B. 1997. Life history, latitudinal patterns, and status of the shortnose sturgeon, Acipenser brevirostru. Environmental Biology of Fishes 48: 319-334.

Lambrecht B. 2005. Big Muddy Blues: True Tales and Twisted Politics Along Lewis and Clark's Missouri River. Thomas Dunne Books: New York; 352

Laustrup MS, Jacobson RB, Simpkins DG. 2007. Distribution of Potential Spawning Habitat for Sturgeon in the Lower Missouri River. Open-File Report 2007-1192. U.S. Geological Survey: Reston, VA; 26. http://pubs.usgs.gov/of/2007/1192/ [accessed 31 March 2008].

Ligon FK, Dietrich WE, Trush WJ. 1995. Downstream ecological effects of dams. Bioscience 45: 183-192.

Lucas MC, Baras E. 2001. Migration of Freshwater Fishes. Blackwell Scientific: Oxford; 440.

Lubinski KS, Barko JW. 2003. Upper Mississippi River - Illinois Waterway System Navigation Feasibility Study: Environmental Science Panel Report: Interim Report for the Upper Mississippi River - Illinois Waterway System Navigation Study, ENV Report 52. U.S. Army Corps of Engineers: Rock Island, IL; 79.

Mayden RL, Kuhajda BR. 1997. Threatened fishes of the world: Scaphirhynchus albus (Forbes \& Richardson, 1905) (Acipenseridae). Environmental Biology of Fishes 48: 420-421.

Moos RE. 1978. Movement and reproduction of shovelnose sturgeon Scaphirhynchus platorynchus (Rafinesque) in the Missouri River, South Dakota. PhD dissertation, Vermillion, S. Dak., University of South Dakota, 213

National Research Council. 2002. The Missouri River Ecosystem, Exploring the Prospects for Recovery. National Academy Press: Washington, DC; 176.

National Weather Service. 2006. Definitions and General Terminology. National Weather Service Manual 10-950: Washington, DC; 4.

Noakes DLG, Beamish FWH, Rossiter A. 1999. Conservation implications of behaviour and growth of the lake sturgeon, Acipenser fulvescens, in northern Ontario. Environmental Biology of Fishes 55: $135-144$.

Ostdahl T, Taugbol T, Andersen O, Vitterso J. 2001. Stakeholder attitudes to river modification and restoration. In River Restoration in Europe-Practical Approaches, Conference Proceedings, Nijland HJ, Cals MJR (eds). Institute for Inland Water Management and Waste Water Treatment RIZA, Wageningen University: The Netherlands; 315.

Pahl-Wostl C, Sendzimir J, Jeffrey P, Aerts J, Berkamp G, Cross K. 2007. Managing change toward adaptive water management through social learning. Ecology and Society 12: 1-18.

Paragamian VL, Kruse G. 2001. Kootenai River white sturgeon spawning migration behavior and a predictive model. North American Journal of Fisheries Management 21: 10-21.

Paragamian VL, Kruse G, Wakkinen V. 2001. Spawning habitat of Kootenai River White Sturgeon, post-Libby Dam. North American Journal of Fisheries Management 21: 22-33.

Parsley MJ, Beckham LG, McGabe G Jr. 1993. White sturgeon spawning and rearing habitat in the Columbia River downstream from McNeary dam. Transactions of the American Fisheries Society 122: 217-228.

Pflieger WL, Grace TB. 1987. Changes in the fish fauna of the lower Missouri River, 1940-1983. In Community and Evolutionary Ecology of North American Stream Fishes, Mathews W, Heins D (eds). University of Oklahoma Press: Norman, OK; 166-177.
Pigram JJ. 2000. Options for rehabilitation of Australia's Snowy River: an economic perspective. Regulated Rivers-Research \& Management 16: $363-373$

Poff NL, Allan JD, Bain MB, Karr JR, Prestegaard KL, Richter BD, Sparks RE, Stromberg JC. 1997. The natural flow regime. Bioscience 47: 769-784.

Quist MC, Boelter AM, Lovato JM, Korfanta NM, Bergman HL, Latka DC, Korschgen C, Galat DL, Krentz S, Oetker M. 2004. Research and Assessment Needs for Pallid Sturgeon Recovery in the Missouri River-Final report to the U.S. Geological Survey, U.S Army Corps of Engineers, U.S. Fish and Wildlife Service, and U.S. Environmental Protection Agency. William D. Ruckelshaus Institute of Environment and Natural Resources, University of Wyoming: Laramie, WY; 82.

Richter BD, Baumgartner JV, Powell J, Braun DP. 1996. A method for assessing hydrological alteration within ecosystems. Conservation Biology 10: 1163-1174.

Richter BD, Baumgartner JV, Wiginton R, Braun DP. 1997. How much water does a river need? Freshwater Biology 37: 231-249.

Richter BD, Mathews R, Harrison DL, Wigington R. 2003. Ecologically sustainable water management-Managing river flows for ecological integrity. Ecological Applications 13: 206-224.

Richter BD, Warner AT, Meyer JL, Lutz K. 2006. A collaborative and adaptive process for developing environmental flow recommendations. River Research and Applications 22: 297-318.

Robinson C, Whitton S. 2004. Fisheries action plans-A new approach to public consultation and the impetus for habitat enhancement works in the upper Thames catchment (England). In River Restoration 2004-Principles, Processes, Practices.-Proceedings of the 3rd ECRR International Conference on River Restoration in Europe, Geres D (ed.). European Center for River Restoration: Zagreb; $315-323$.

Rogers K. 2006. The real river management challenge: integrating scientists, stakeholders and service agencies. River Research and Applications 22: 269-280.

Rogers KH, O'Keeffe J. 2003. River heterogeneity: Ecosystem structure, function, and management. In The Kruger Experience: Ecology and Management of Savanna Heterogeneity, Du Toit J, Biggs $\mathrm{H}$, Rogers KH (eds). Island Press: Washington, DC; 519.

Rohlf DJ. 1991. Six biological reasons why the Endangered Species Act doesn't work and what to do about it. Conservation Biology 5: 273-282.

Schmidt JC, Wilcock PR. Metrics for assessing the downstream effects of dams. Water Resources Research 44: 53, DOI: 10.1029/2006WR005092.

Sklar FH, Chimney MJ, Newman S, McCormick P, Gawlik D, Miao S, McVoy C, Said W, Newman J, Coronado C, Crozier G, Korvela M, Rutchey K. 2005. The ecological-societal underpinnings of Everglades restoration. Frontiers in Ecology and the Environment 3: 161-169.

Stewardson MJ, Gippel CJ. 2003. Incorporating flow variability into environmental flow regimes using the flow events method. River Research and Applications 19: 459-472.

Tharme RE. 2003. Global perspective on environmental flow assessment: emerging trends in the development and application of environmental flow methodologies for rivers. River Research and Applications 19: $397-441$.

The Nature Conservancy. 2005. Indicators of Hydrologic Alteration, Version 7, User's Manual, 42.

Thorson JE. 1994. River of Promise, River of Peril-The Politics of Managing the Missouri River. University Press of Kansas: Lawrence, $\mathrm{KS} ; 284$.

Tracy-Smith E. 2006. Relation of missouri river flows to sandbar morphology with implications for selected biota. Master's Thesis, University of Missouri, Columbia, 177

U.S. Army Corps of Engineers. 1998. Reservoir Regulation Studies-Daily Routing Model Studies, Master Water Control Manual Missouri River Review and Update Study, Vol. 2A. U.S. Army Corps of Engineers, Northwest Division: Omaha, NE; 137.

U.S. Army Corps of Engineers. 2003a. Final Biological Assessment on the Operation of the Missouri River Mainstem Reservoir System, the Operation and Maintenance of the Bank Stabilization and Navigation Project, and the Operation of the Kansas River Reservoir System. U.S. Army Corps of Engineers, Northwestern Division, Missouri River Basin Water Management Division: Omaha, NE; 29.

U.S. Army Corps of Engineers. 2003b. Supplemental Biological Assessment for the Current Water Control Plan. U.S. Army Corps of Engineers, Northwestern Division, Missouri River Basin Water Management Division: Omaha, NE; 24. 
U.S. Army Corps of Engineers. 2004a. Missouri River Stage Trends. U.S. Army Corps of Engineers, Northwestern Division, Reservoir Control Center Technical Report A04: Omaha, NE; 43.

U.S. Army Corps of Engineers. 2004b. Summary Missouri River Final Environmental Impact Statement-Master Water Control Manual Review and Update. U.S. Army Corps of Engineers, Northwest Division: Portland, OR; 28.

U.S. Army Corps of Engineers. 2006. Missouri River Mainstem System-2005-2006 Annual Operating Plan. Northwestern Division, Missouri River Basin, Water Management Division: Omaha, NE; 89.

U.S. Fish and Wildlife Service. 2000. Biological Opinion on the Operation of the Missouri River Main Stem Reservoir System, Operation and Maintenance of the Missouri River Bank Stabilization and Navigation Project, and Operation of the Kansas River Reservoir System. U.S. Fish and Wildlife Service: Bismarck, ND; 286.

U.S. Fish and Wildlife Service. 2003. Amendment to the 2000 Biological Opinion on the Operation of the Missouri River Main Stem Reservoir System, Operation and Maintenance of the Missouri River Bank Stabilization and Navigation Project, and Operation of the Kansas River Reservoir System. U.S. Fish and Wildlife Service: Minneapolis, $\mathrm{MN} ; 308$.
U.S. Fish and Wildlife Service. 2007. Pallid Sturgeon (Scaphirhynchus Albus) 5-Year Review: Summary and Evaluation. U.S. Fish and Wildlife Service: Billings, MT; 120.

Walters C. 1997. Challenges in adaptive management of riparian and coastal systems. Conservation Biology 12: 22.

Welcomme RL. 1985. River Fisheries. Food and Agriculture Organization Fisheries, Technical Paper 262: Rome; 330.

Wildhaber ML, DeLonay AJ, Papoulias DM, Galat DL, Jacobson RB, Simpkins DG, Braaten PJ, Korschgen CE, Mac MJ. 2007. A Conceptual Life-History Model for Palld and Shovelnose Sturgeon, U.S. Geological Survey Circular 1315; Reston, VA; 18 http://pubs.usgs.gov/ circ/2007/1315/ [accessed 31 March 2008].

Zockler C, Wenger E, Madgwick J. 2001. Assessment of WWF river and floodplain restoration proejcts in Europe. In River Restoration in Europe-Practical Approaches, Conference Proceedings, Nijland HJ, Cals MJR (eds). Institute for Inland Water Management and Waste Water Treatment RIZA, Wageningen University: The Netherlands; $73-82$. 